\title{
Animal husbandry in the Early and Middle Neolithic settlement at Kopydłowo in the Polish lowlands. A multi-isotope perspective
}

\author{
Arkadiusz Marciniak $^{1}$ - Jane Evans ${ }^{2}$ • Elizabeth Henton ${ }^{3}$. Jessica Pearson ${ }^{4}$. \\ Mikołaj Lisowski $^{5}$ - Marta Bartkowiak ${ }^{1}$ - Iwona Sobkowiak-Tabaka ${ }^{6}$
}

Received: 26 March 2016 / Accepted: 1 March 2017 / Published online: 12 April 2017

(C) The Author(s) 2017. This article is published with open access at Springerlink.com

\begin{abstract}
The aim of this article is to examine the isotopic characterisation of domestic animals as it relates to birthing location and seasonality, diet, pasturing pattern, foddering and climatic conditions of herding and to determine variation between these aspects of cattle and caprine husbandry of the Neolithic Linearbandkultur (LBK) and Trichterbecherkultur (TRB) communities from Kopydłowo in Kujavia — one of the major centres of early farming in the European lowlands. Carbon and nitrogen stable isotope analysis was undertaken on faunal bone collagen; carbon, oxygen and strontium isotope ratios were measured from tooth enamel. Isotopic signatures may have been caused by different strategies of management of herds of these animal species. Different and more widely distributed carbon, nitrogen and strontium isotopic data for TRB cattle in comparison with its LBK counterparts is indicative of the exploitation of increasingly diverse ecological zones and more varied pastoral practises. The distribution of oxygen isotope values on caprine tooth made it possible to
\end{abstract}

Arkadiusz Marciniak

arekmar@amu.edu.pl

1 Institute of Archaeology, Adam Mickiewicz University, Umultowska 89D, 61-614 Poznań, Poland

2 NERC Isotope Geosciences Laboratory, British Geological Survey, Keyworth, Nottingham NG12 5GG, UK

3 Institute of Archaeology, University College London, 31-34 Gordon Square, London WC1H OPY, UK

4 Archaeology, Classics and Egyptology, University of Liverpool, 12-14 Abercromby Square, Liverpool L69 7WZ, UK

5 Department of Archaeology, University of Sheffield, Northgate House Wall Street, Sheffield S1 4ET, UK

6 Institute of Archaeology and Ethnology, Polish Academy of Sciences, Rubież 46, 61-612 Poznań, Poland recognise herding seasonality. Irrespective of the chronology, cattle, sheep and goats kept by the inhabitants had $\mathrm{C}_{3}$ plantbased diet.

Keywords European Neolithic · Linearbandkultur · Trichterbecherkultur · Animal husbandry $\cdot$ Stable isotopes

\section{Introduction}

The most important domesticated species in the Early and Middle Neolithic of the Polish lowlands are cattle, sheep, goat, pig and dog. As indicated by faunal evidence, cattle are the most frequent species, often representing more than $50 \%$ of the identified bones. Their meat is believed to make the biggest contribution to the diet (e.g. Bogucki 1988; Marciniak 2005, 2013a) but other products such as cheese and milk were also important dietary components (e.g. Salque et al. 2012; Evershed et al. 2008). Sheep and goat were most often the second preferred species followed by pig. Species composition in addition to age-at-death determinations has been used to discern the pattern of herd management. Zooarchaeological studies have recently been enriched by the developments outside the realm of this discipline, such as the study of ceramic lipids or bone and tooth enamel collagen stable isotopes, which can effectively contribute to an in-depth understanding of the complex nature of animal production and exploitation (e.g. Pearson et al. 2007; Hongo et al. 2009; Marciniak 2014). Stable isotopes, in particular carbon, nitrogen, oxygen and strontium, are of significant heuristic potential, in particular whilst combined with the results of faunal studies. Increasing numbers of stable isotope measurements of fauna remains have shown how wild animals can be tentatively distinguished from domestic animals (Balasse et al. 2016; Hongo et al. 2009) and how the increasing management and later herding 
of animals can be detected through changes in animal diet as herbivory preference by individual species is replaced by food provided by pastoralists (Pearson et al. 2007; Szpak et al. 2014; Cucchi et al. 2016. The interpretation of these isotopes in combination have been used to good effect at Neolithic Çatalhöyük, Central Anatolia (Bogaard et al. 2014; Pearson et al. 2015) and central Europe (Bickle and Whittle 2013).

The aims of the carbon and nitrogen stable isotope analyses are to assess the evidence for changes in animal diet that would point to differences in animal management and herding strategies across the LBK and TRB periods. Stable isotope analyses have shown great potential for understanding these practises from a range of time periods. In the LBK in Germany, Oelze et al. (2011) reported that aurochs and domestic cattle in LBK Germany had different diets, suggestive of feeding in different locations, whilst Fraser et al. (2013a, b) suggest that pigs and cattle were likely kept and herded locally. Pearson et al. (2007) showed how stable carbon and nitrogen values in the bone collagen of sheep and goats in Neolithic Anatolia differed according to hunting, management and herding regimes as sites expanded from small- to largescale communities. Szpak et al. (2014) illustrated how camelids in Northern Peru during the Early Intermediate Period were likely being managed by small social units, possibly family groups. Most recently, Cucchi et al. (2016) have shown how carbon and nitrogen stable isotope analysis of pig bone collagen enabled an investigation of animal husbandry and increasing social complexity in ancient China.

The major sources of isotope variation in a food web relate to the environment in which an animal lives and the foods it consumes there. The movement of carbon through the food chain results in average trophic level shifts of $\sim 5 \%$ o between plants and herbivores collagen, and $\sim 1 \%$ o between herbivore and carnivore (DeNiro and Epstein 1978). For nitrogen, the trophic level is an average of $\sim 4 \%$ (Hedges and Reynard 2007). Much of the variation is assimilated from plants, which themselves are affected by the soils on which they grow. Wild and domestic ungulates consume two types of plants as the bulk of their diet: $\mathrm{C}_{3}$ and $\mathrm{C}_{4}$ plants. Greater isotopic discrimination against the heavier isotope ${ }^{13} \mathrm{C}$ during $\mathrm{C}_{3}$ photosynthesis results in distinctive isotope values for $\mathrm{C}_{3}$ versus $\mathrm{C}_{4}$ plants. Carbon isotope values in global $\mathrm{C}_{3}$ plants typically range between: -34 and $-22 \%$, whilst in $\mathrm{C}_{4}$ plants this range is between -20 and $-7 \%$ o (O'Leary 1981). One of the key $\mathrm{C}_{4}$ crop plants in central Europe would have been millet (Hunt et al. 2008), but it is not clear how abundant other wild $\mathrm{C}_{4}$ plants would have been that may have been available to animals. $\mathrm{C}_{4}$ plants are thought to be generally avoided by most animals, due to their poorer nutritional quality relative to $\mathrm{C}_{3}$ plants (Heckathorn et al. 1999), although these plants have been used as foddering by humans in the past (e.g. Copley et al. 2003; Fuller et al. 2012; Cucchi et al. 2016). More modest sources of isotope variation are often the result of local conditions: temperature, rainfall, canopy effect of dense woodland and soil nutrient content (Tieszen 1991; Van der Merwe and Medina 1991; Glagoleva and Chulanovskaya 1992; Tieszen and Fagre 1993; Heaton 1999).

Nitrogen isotope values in consumers are also influenced by a range of environmental and physiological factors, most of which result in raised nitrogen isotope values. In plants, these are aridity (e.g. Heaton 1987; Ambrose 1991; Cormie and Schwarcz 1994; Gröcke et al. 1997; Schwarcz et al. 1999) and soil salinity (e.g. van Groenigen and van Kessel 2002; Robinson et al. 2000). In animals, these include the physiological effects of environmental phenomena including body water conservation (Ambrose 2000), rumination in animals such as sheep and cattle (Macko et al. 1982; Sealy et al. 1987; Wattiaux and Reed 1995; Cormie and Schwarcz 1996) and starvation (Fuller et al. 2005; cf. Barboza et al. 1997; Ambrose 2000; Faber et al. 2003; Stewart and Smith 2005). In addition, Bogaard et al. (2007) and Fraser et al. (2013a, b) have shown that manuring also causes ${ }^{15} \mathrm{~N}$ enrichment and higher nitrogen isotope values in crops.

Isotopic analyses of sequential enamel samples have the resolution to provide seasonal information on herd management practises (Balasse et al. 2002, 2003; Fricke and O'Neil 1996; Henton 2012). Oxygen isotope sequences in Ovis/ Capra were used to elucidate the seasonality of water ingested within their food (Bryant and Froelich 1995; Iacumin and Longinelli 2002). Tooth enamel is sequentially deposited over a fixed period without re-modelling (Weinreb and Sharav 1964); in caprine second and third molars formation takes approximately 1 year (Suga 1982). In caprine tissue, oxygen is primarily sourced from ingested water derived ultimately from precipitation, and the ratio of its isotopes varies with climate and with seasonal changes in temperature and precipitation (Dansgaard 1964; Rozanski et al. 1993). The seasonal signature can, however, be lost if ingested water derives from large reservoirs of mixed-season water (Darling 2004), if the animals are moved to areas with different temperature and precipitation regimes (Poage and Chamberlain 2001) or if they are foddered on food collected out of season.

The objective of this article is to use carbon, nitrogen, oxygen and strontium isotopes from a Neolithic settlement at Kopydłowo in the southern part of Kujavia in the Polish lowlands to address different facets of cattle and caprine husbandry practises. The settlement was occupied by the first Early Neolithic farming groups of the Linearbandkultur (LBK) in the lowlands and then by the first genuinely indigenous Middle Neolithic farmers of Trichterbecherkultur (TRB). An application of the multi-isotope approach with its unprecedented heuristic potential makes it possible to address a complex character of cattle and caprine husbandry of early farming groups and reflect the hitherto unexplored dimension of existence of two distinctively different Neolithic communities occupying the lowlands areas of northern Europe. In particular, 
the article addresses birthing place and season, diet, foddering, the movement of cattle and caprines across landscapes, including seasonality and pasture location of both herds, as well as potential impact on inter-annual climate variations in rainfall, temperature and seasonality onto herding strategies.

\section{The settlements at Kopydlowo and the central European Neolithic}

The first Neolithic communities of the LBK culture in the lowlands of central Europe appeared ca. 5500-5400 cal BC (Czerniak 1998, 23; Milisauskas and Kruk 1989, 404). These earliest groups of the so-called Danubian Neolithic immigrated to the lowlands from the south. LBK sites are scattered throughout the Polish lowlands-in Kujavia, Chełmno Land and Pyrzyce along the lower Oder-almost exclusively on fertile rich brown and black soils, similar in quality to the loess soil of the uplands. The period following the demise of the LBK in the Polish lowlands at the end of the 6th millennium BC brought about a complete disintegration of the hitherto dominant cultural and social arrangements. The first half of the 5th millennium BC marked the discontinuous development of new forms of spatial organisation in all major parts of the early Neolithic oecumene in the Polish lowlands. In the second half of the 5th millennium cal BC, a completely different picture of lowland Neolithic communities emerged and represented by the Late Lengyel culture. These were fully fledged farming communities organised in the form of individual households (e.g. Grygiel 2008; Grygiel and Bogucki 1997). The demise of these arrangements towards the end of the 5 th millennium BC marks the end of the Danubian Neolithic. The emergence of the TRB in the following millennium marked the beginning of a new phase in the development of the Neolithic on the North European Plain. These groups were formed as a result of the increasingly independent development of lowlands framers, far distanced from any external influences, additionally strengthened by the systematically developing relations with local foragers. These can rightly be defined as the first genuinely local farming groups of the Polish lowlands. They exploited increasingly diverse ecological zones by applying a number of diverse exploitation strategies involving exploitation of areas with poor soils or forested zones (see Marciniak 2008).

This trajectory of development of local communities in the Polish lowlands is well manifested at the settlement at Kopydłowo, site 6 (see Marciniak et al. 2015a). It is located in the southern part of Kujavia, near its western border with Greater Poland (Fig. 1). The site was excavated in the years 1984-1985 but unearthed materials have only been analysed very recently as a part of the large-scale project funded by the Polish Ministry of Culture and National Heritage. Altogether, an area of ca.

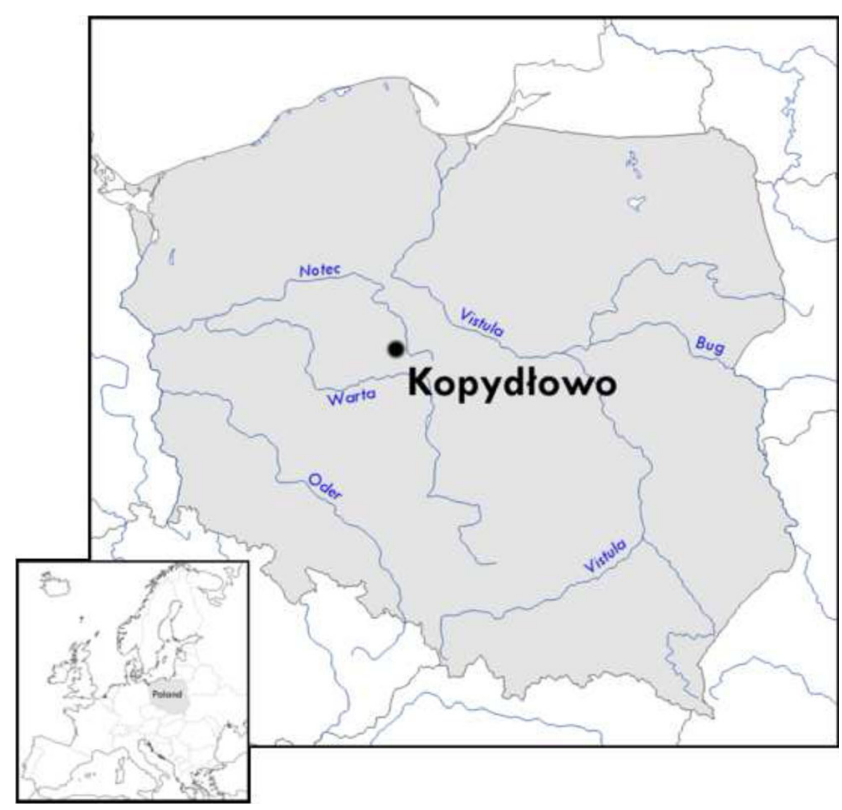

Fig. 1 Kopydłowo, site 6. Location of the site

3 acres has been excavated. It led to the discovery of 62 archaeological features (Fig. 2), most of which dated to the LBK, Late Lengyel and TRB cultures, over 7000 pottery sherds, ca. 2700 animal bones and over 200 flint artefacts, in addition to a number of materials that are post-Neolithic in date. A small part of the Late Lengyel settlement has also been discovered. The LBK settlement from phase IIA (the so-called Note phase) is represented by two pits (25B and 25C) with numerous artefacts. The Late Lengyel settlement is represented by four pits and a burial in addition to pottery sherds. Remains of the TRB culture, dated to classic Wiórecka, i.e. IIIB-IIIC phase, are much more numerous. They are represented by pits of different function and character as well as postholes indicative of the presence of large house (Marciniak et al. $2015 b$ ). Due to a dearth of faunal material from the Late Lengyel settlement, the article is focused on husbandry practises in the LBK and TRB groups. The data from the Late Langyel community are only used in places for a comparative purpose.

The bone assemblage from LBK and TRB settlements at Kopydłowo derive from household post-consumption refuse and bone working. The majority of bones were found in a few sunken featured buildings. One of TRB pits included a stack of cattle, aurochs and goat horn cores used for horn working (Lisowski 2014, 2015). The LBK assemblage (minimum number of elements, $N=97$ ) is dominated by cattle (45.4\%), followed by pigs $(30.9 \%)$ and caprine $(7.2 \%)$ (Lisowski 2015). The TRB assemblage (MNE $N=234$ ) has a similar composition with cattle being the most common species (55.1\%), followed by pigs (25.2\%) and then caprine (12.0\%) (Lisowski 2015). 

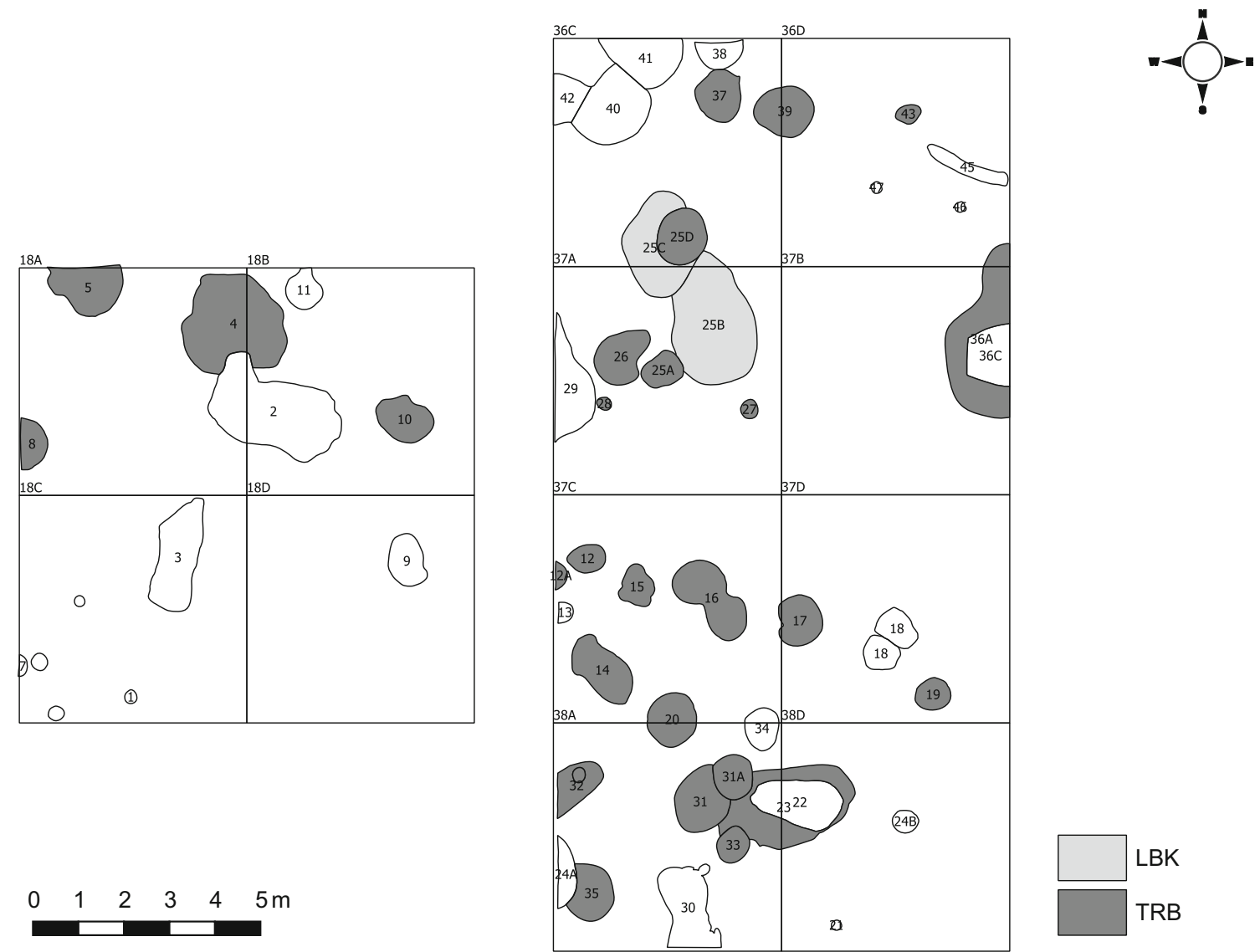

Fig. 2 Kopydłowo, site 6. A plan of the excavation areas and distribution of archaeological features

\section{Materials and methods}

Bone and teeth remains recovered from archaeological features from the LBK and TRB Kopydłowo settlements have been analysed isotopically. Altogether, bone collagen from 29 cattle and caprine specimens was subjected to carbon and nitrogen analyses (Table 1). Five Kopydłowo caprine molars were subjected to sequential oxygen isotopic analyses of the enamel (Table 2). Strontium isotope of nine samples of tooth enamel were measured to determine the life signal of the source animal and three bone samples were analysed to give an indication of the local burial values at the site (Table 3 ). In this article, we use $0.005 P$ value as the threshold for a statistically significant result.

Samples for bone collagen extraction were taken as a chunk of compact cortical bone (c.500 mg) using a diamond powder-coated cutting wheel from the broken end of the bone diaphysis avoiding articulations, cut marks, pathologies, glue and identification number. All reagents used were analytical grade (AR/Analar); water used was of ultrapure $(18.2 \mathrm{M} \Omega$ ) quality. The bone collagen extraction protocol follows the modified Longin (1971) method (Brown et al. 1988). Collagen integrity was assessed using the atomic $\mathrm{C} / \mathrm{N}$ ratio range of $2.9-3.6, \% \mathrm{C}$ range of $22.6-47.0 \%$, and $\% \mathrm{~N}$ range of 8.1-16.6\% criteria of DeNiro (1985) and Ambrose (1993). All samples with ratios outside of the acceptable ranges for these were discarded. They were measured in duplicate at the NERC Isotope Geosciences Laboratory (NIGL), UK, and analysed using an Elemental Analyzer (Flash/EA) coupled to a Thermo Finnigan Delta ${ }^{\text {Plus }}$ XL isotope ratio mass spectrometer via a ConFlo III interface. All data are reported driftcorrected and measurement precision was $0.1 \%$ o for both carbon and nitrogen.

Samples for stable isotope ratio analysis of oxygen were retrieved and prepared following methods established by Balasse (2002). The mesial tooth column buccal surface of each specimen was cleaned, and six sequential samples of c15mg were drilled at measured distances from the enamelroot junction (Fig. 3); contamination and diagenetic carbonates were removed following Balasse et al. (2002). The carbonate fraction of each sample was analysed for $\delta^{18} \mathrm{O}$ by isotope ratio mass spectrometry at UCL Bloomsbury Environment Isotope Facility on their ThermoFinnigan DeltaPLUS XP stable isotope mass spectrometer attached to a ThermoScientific Gas Bench II. The raw data is presented in Table 2. Interpretation of the oxygen isotope data draws on a model constructed from monthly data collected over a number of years from four stations within $300 \mathrm{~km}$ of Kopydłowo 
Table 1 Kopydłowo, site 6 . Results of $\delta^{13} \mathrm{C}$ and $\delta^{15} \mathrm{~N}$ : analyses of collagen samples

\begin{tabular}{|c|c|c|c|c|c|c|c|c|c|}
\hline Sample name & Feature & Culture & Species & Element & $\% \mathrm{C}$ & $\% \mathrm{~N}$ & Atomic C:N & $\delta 13 \mathrm{C}$ PDB $(\% \circ)$ & $\delta 15 \mathrm{~N}$ AIR $(\% o)$ \\
\hline KOP25 & $25 \mathrm{~B}$ & LBK & Caprine & Humerus & 36.5 & 12.6 & 3.4 & -20.5 & 5.7 \\
\hline KOP27A & $25 \mathrm{~B}$ & LBK & Caprine & Radius & 41.6 & 15.1 & 3.2 & -19.8 & 6.7 \\
\hline KOP28 & $25 \mathrm{C}$ & LBK & Caprine & Metatarsal & 24.0 & 8.2 & 3.4 & -20.3 & 7.7 \\
\hline KOP1 & $25 \mathrm{~B}$ & LBK & Cattle & Tibia & 37.5 & 13.0 & 3.4 & -20.8 & 6.3 \\
\hline KOP10 & $25 \mathrm{~B}$ & LBK & Cattle & Radius & 36.8 & 13.1 & 3.3 & -20.4 & 6.3 \\
\hline KOP11 & $25 \mathrm{~B}$ & LBK & Cattle & Metacarpal & 43.0 & 15.7 & 3.2 & -19.9 & 6.0 \\
\hline KOP12 & $25 \mathrm{~B}$ & LBK & Cattle & Metacarpal & 35.5 & 11.6 & 3.6 & -20.1 & 6.6 \\
\hline KOP24 & $25 \mathrm{~B}$ & LBK & Cattle & Phalanx 1 & 42.5 & 14.9 & 3.3 & -20.2 & 6.4 \\
\hline KOP26 & $25 \mathrm{C}$ & LBK & Cattle & Phalanx 2 & 41.7 & 13.9 & 3.5 & -20.7 & 6.7 \\
\hline KOP7 & $25 \mathrm{C}$ & LBK & Cattle & Phalanx 2 & 35.0 & 12.1 & 3.4 & -21.0 & 6.0 \\
\hline KOP8 & $25 \mathrm{C}$ & LBK & Cattle & Astragalus & 38.4 & 14.1 & 3.2 & -20.2 & 6.2 \\
\hline KOP9 & $25 \mathrm{~B}$ & LBK & Cattle & Metatarsal & 36.1 & 12.5 & 3.4 & -20.8 & 6.0 \\
\hline KOP5 & 36 & LBK/TRB & Sheep & Radius & 42.7 & 15.6 & 3.2 & -20.0 & 6.2 \\
\hline KOP04 & 4 & TRB & Caprine & Radius & 37.6 & 12.8 & 3.4 & -21.0 & 6.7 \\
\hline KOP30 & 31 & TRB & Caprine & Metacarpal & 40.5 & 14.8 & 3.2 & -19.9 & 5.9 \\
\hline KOP16 & 4 & TRB & Cattle & Radius & 36.3 & 13.2 & 3.2 & -21.1 & 7.8 \\
\hline KOP13 & 4 & TRB & Cattle & Femur & 41.5 & 14.6 & 3.3 & -21.2 & 7.2 \\
\hline KOP14 & 5 & TRB & Cattle & Metacarpal & 35.6 & 12.4 & 3.4 & -20.6 & 8.2 \\
\hline KOP18 & 31 & TRB & Cattle & Skull & 46.3 & 15.5 & 3.5 & -20.2 & 8.3 \\
\hline KOP19 & 31 & TRB & Cattle & Skull & 42.8 & 15.5 & 3.2 & -20.7 & 6.3 \\
\hline KOP20 & 31 & TRB & Cattle & Radius & 38.8 & 13.7 & 3.3 & -22.1 & 6.7 \\
\hline KOP21 & $4 \mathrm{~A}$ & TRB & Cattle & Humerus & 28.7 & 9.4 & 3.6 & -22.7 & 6.8 \\
\hline KOP22 & $4 \mathrm{~A}$ & TRB & Cattle & Metatarsal & 41.3 & 14.5 & 3.3 & -21.2 & 7.6 \\
\hline KOP29 & $4 \mathrm{~A}$ & TRB & Cattle & Radius & 38.0 & 13.6 & 3.3 & -21.0 & 8.7 \\
\hline KOP3 & $4 \mathrm{~A}$ & TRB & Cattle & Phalanx 1 & 44.9 & 15.2 & 3.5 & -21.0 & 7.7 \\
\hline KOP6A & 31 & TRB & Cattle & Skull & 38.5 & 13.7 & 3.3 & -21.7 & 7.0 \\
\hline $\mathrm{KOP} 2$ & 31 & TRB & Cattle/Aurochs & Skull & 36.8 & 11.9 & 3.6 & -21.4 & 6.8 \\
\hline KOP15 & 31 & TRB & Goat & Skull & 41.8 & 15.0 & 3.3 & -21.0 & 8.2 \\
\hline KOP23 & 31 & TRB & Goat & Skull & 42.5 & 15.6 & 3.2 & -20.4 & 7.7 \\
\hline
\end{tabular}

(IAEA/WMO 2014) (Table 4), which was used to model the seasonal distribution of oxygen isotopic values at both Neolithic settlements (Fig. 4).

Samples for stable isotope ratio analysis of strontium were prepared as described in Neil et al. (2016). Strontium was loaded onto a single Re Filament following the method of Birck (1986), and the isotope composition and concentrations were determined by thermal ionization mass spectroscopy (TIMS) using a Thermo Triton multi-collector mass spectrometer. The international standard for ${ }^{87} \mathrm{Sr} /{ }^{86} \mathrm{Sr}$, NBS987, gave a value of $0.710250 \pm .000006(n=8,2 \sigma)$ during the analysis of these samples. Blank values are better than $100 \mathrm{pg}$ (Table 3). All samples were measured at the NERC Isotope Geosciences Laboratory (NIGL), UK. It is important to stress that because of the high porosity of the bone, the $\mathrm{Sr}$ isotope composition determined will be dominated a diagenetic signal reflecting the burial area and will not reflect a life signal. As the bone is taking up strontium from the soil during burial, the $\mathrm{Sr}$ concentrations in it are so high.

Different facets of cattle and caprine herd management strategies at settlements of both cultures at Kopydłowo recognised isotopically were then considered alongside with their picture by zoorchaeological methods, in particular the estimation of age-at-death (Vigne and Helmer 2007, Marciniak 2011). It was assessed using mandibular teeth wear and eruption following Payne (1973) for sheep/goat, and Grant (1982) and Grigson (1982) for cattle. Epiphyseal fusion dates are based on Silver (1969) and were grouped into age stages (cf. Wilson et al. 1978; Halstead 2011). For cattle, 4 stages were distinguished; animals killed (1) before 7 10 months, (2) before 12-18 months, (3) before 24-36 months and (4) before 36-48 months. Sheep and goat bones were divided in 3 stages; animals killed (1) before 7-10 months, (2) before 18-28 months and (3) before 30-42 months (see 


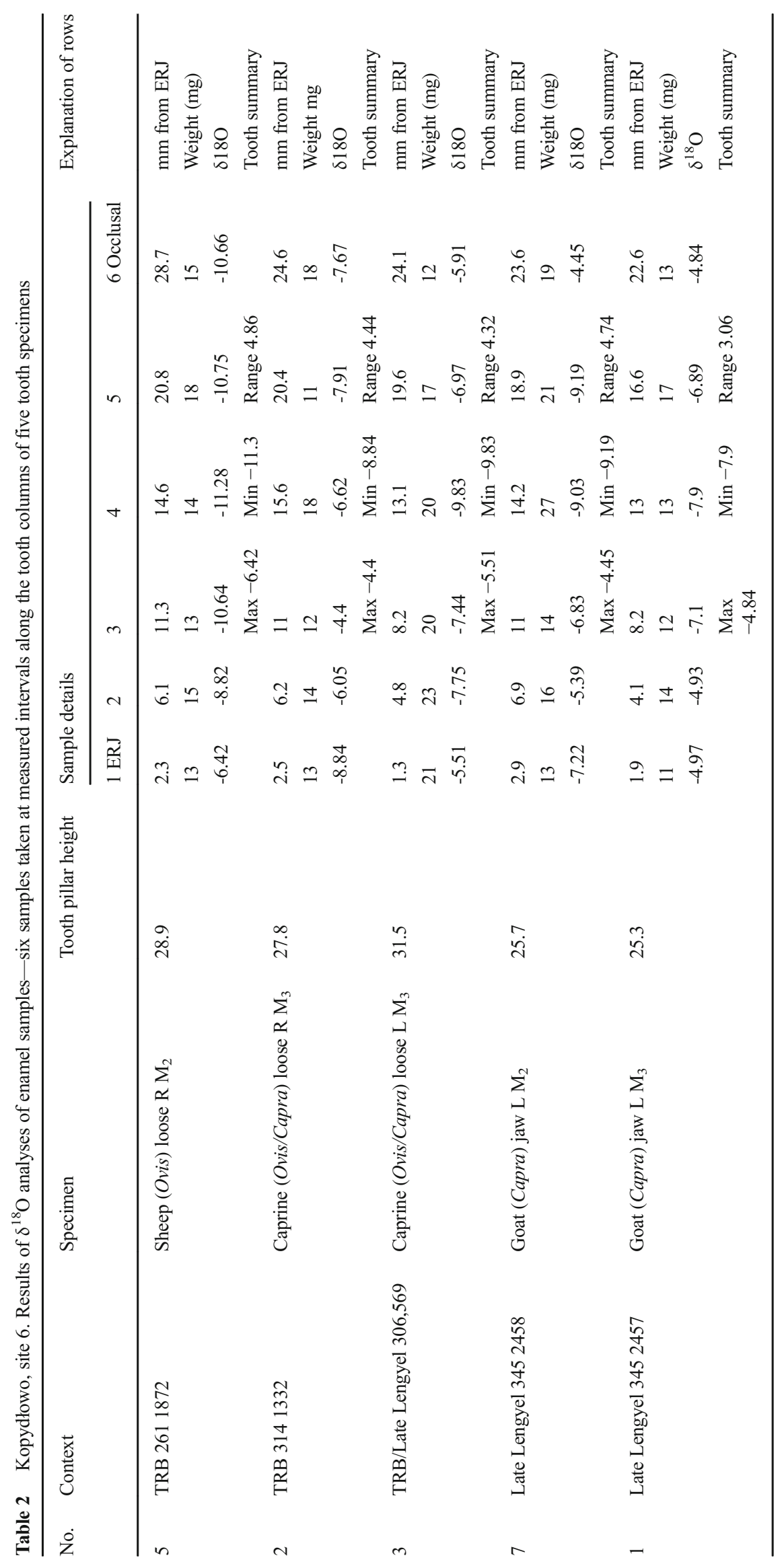


Table 3 Kopydłowo, site 6. The strontium isotope compositions and $\mathrm{Sr}$ concentrations form the enamel and bone samples.

\begin{tabular}{|c|c|c|c|c|c|c|c|}
\hline Inv. No. & Feature & Culture & Sample code & Type of sample & Body part & Sr ppm & $87 \mathrm{Sr} / 86 \mathrm{Sr}$ \\
\hline $\mathrm{k} 6 / 60 / 677$ & 4 & TRB & ML - 01 & enamel - pig & $\begin{array}{l}\text { Mandibular M2 } \\
\text { (with parts of the socket) }\end{array}$ & 148 & 0.71249 \\
\hline $\mathrm{k} 6 / 60 / 673$ & 4 & TRB & ML - 02 & enamel - cattle & Mandibular M2 & 184 & 0.71300 \\
\hline $\mathrm{k} 6 / 92 / 125$ & 5 & TRB & ML - 04 & enamel - cattle & Mandibular M1/2 & 147 & 0.71214 \\
\hline $\mathrm{k} 6 / 228 / 1638$ & 31 & TRB & ML - 06 & enamel - cattle & Maxillar molar & 200 & 0.71301 \\
\hline $\mathrm{k} 6 / 220 / 2261$ & $25 \mathrm{~B}$ & LBK & ML - 07 & enamel - cattle & Mandible (P2, P3, M1, M2) & 117 & 0.71195 \\
\hline k6/207/1912 & $25 \mathrm{~B}$ & LBK & ML - 08 & enamel - pig & Mandibular M2 & 90 & 0.71169 \\
\hline $\mathrm{k} 6 / 220 / 2270$ & $25 \mathrm{~B}$ & LBK & ML - 09 & enamel - cattle & Mandibular M3 & 141 & 0.71199 \\
\hline $\mathrm{k} 6 / 114 / 926$ & $4 \mathrm{~A}$ & TRB & ML - 10 & enamel - cattle & Mandibular M2 & 158 & 0.71269 \\
\hline $\mathrm{k} 6 / 220 / 2262$ & $25 \mathrm{~B}$ & LBK & ML - 15 & enamel - cattle & Mandible (P2, P3, M1, M2) & 160 & 0.71189 \\
\hline $\mathrm{k} 6 / 314 / 1326$ & & & ML - 13 & bone & Bone sample for background value & 308 & 0.712619 \\
\hline k6/100/194 & & & ML - 11 & bone & Bone sample for background value & 253 & 0.712319 \\
\hline $\mathrm{k} 6 / 309 / 464$ & & & ML - 12 & bone & Bone sample for background value & 285 & 0.712735 \\
\hline
\end{tabular}

Lisowski 2015). Due to a small number of mandibles, most of ageing data derives from epiphyseal fusion.

\section{Results}

Cattle, sheep, goats and caprine specimens yielded carbon isotope values ranging from -22.7 to $-19.8 \%$ and from 5.7 to $8.7 \%$ in case of nitrogen isotope values (Table 1). The results of 8 collagen samples from sheep, goats and caprines (specimens that could not be identified with confidence to sheep or goat) are as follows: the single sheep has a carbon isotope value of $-20.0 \%$ and a nitrogen isotope value of $6.2 \%$. The carbon and nitrogen isotope values of the two goats differ from each other to a small degree $\left(\delta^{13} \mathrm{C}\right.$ $-21.0 \%$ o, $\delta^{15} \mathrm{~N} 8.2 \%$ and $\delta^{13} \mathrm{C}-20.4 \%$ o, $\delta^{15} \mathrm{~N} 7.7 \%$ ). The results of five caprines range from -21.0 to $-19.8 \% o$ in carbon isotope values and 5.7 to $7.7 \%$ in nitrogen isotope values.
These values have a mean of -20.3 and $6.5 \%$ and one standard deviation of 0.5 and $0.8 \%$. The results of 21 collagen samples from Bos spp. (cattle and possible aurochs) are as follows: the carbon isotope range is -22.7 to $-19.9 \%$ and in nitrogen the range is 6.0 to $8.7 \%$ with mean ratios of -20.9 and $6.9 \%$, and a standard deviation of 0.7 and $0.8 \%$ in carbon and nitrogen, respectively. Within the two chronological periods, the Bos pp. data is distributed as follows. For the LBK period, the ${ }^{13} \mathrm{C}$ range is -21.0 to $-19.9 \%$, the mean is $-20.5 \% o$ and the standard deviation $0.4 \%$ and in $\delta^{15} \mathrm{~N}$ the range is 6.0 to $6.7 \%$, the mean is $6.3 \%$ and the standard deviation $0.3 \%$. For the TRB period, the $\delta^{13} \mathrm{C}$ range is -22.7 to $-20.2 \%$ o, the mean is $-21.2 \%$ ond the standard deviation $0.7 \%$ and in $\delta^{15} \mathrm{~N}$ the range is 6.3 to $8.7 \%$, the mean is $7.4 \%$ and the standard deviation also $0.7 \%$ o. Comparing the cattle across the two periods, Student's $t$ test indicated a significant difference was found in both carbon $(p=0.003)$ and nitrogen $(p=<0.001)$ ratios, suggesting that the two cattle
Fig. 3 Typical enamel development in an ungulate molar, with a hypothetical graph constructed from isotope values in sequential samples

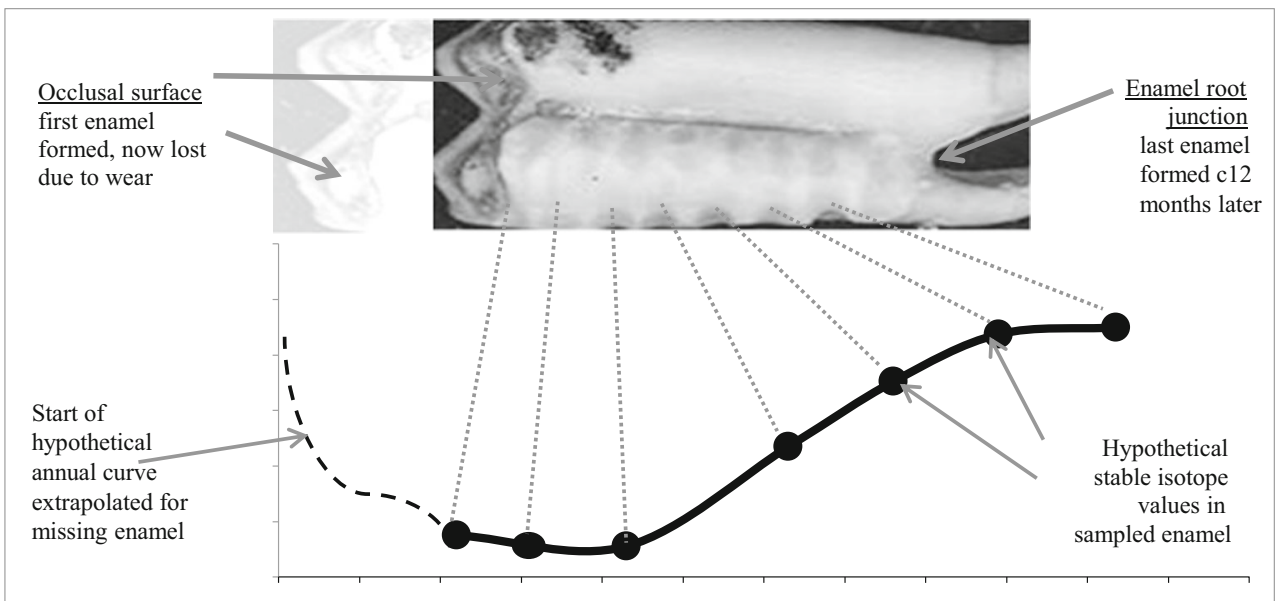


Table 4 Geospatial information on Kopydłowo and nearby GNIP collecting stations, including GNIP station average maximum and minimum seasonal $\delta^{18} \mathrm{O}_{\text {VSMOW }}$ values (data retrieved 30.04.2015) and modelled Kopydłowo values extrapolated from Brest and Berlin GNIP data

\begin{tabular}{|c|c|c|c|c|c|c|c|}
\hline $\begin{array}{l}\text { Collection station } \\
\text { (no years) }\end{array}$ & $\begin{array}{l}\text { Position } \\
\text { relative to } \\
\text { Kopydłowo }\end{array}$ & Map coordinate & $\begin{array}{l}\text { Altitude } \\
\text { masl }\end{array}$ & Climate & $\begin{array}{l}\text { Average } \\
\text { maximum } \\
\delta^{18} \mathrm{O}_{\mathrm{VSMOW}} /\end{array}$ & $\begin{array}{l}\text { Average } \\
\text { minimum } \\
\delta^{18} \mathrm{O}_{\text {vSMOW }} /\end{array}$ & $\begin{array}{l}\text { Range in } \\
\delta^{18} \mathrm{O}_{\mathrm{VSMOW}} \%\end{array}$ \\
\hline Kraków, Poland (34) & $215 \mathrm{~km} \mathrm{SSE}$ & $50^{\circ} 3^{\prime} 42^{\prime \prime} 19^{\circ} 50^{\prime} 55^{\prime}$ & 205 & \multirow{5}{*}{$\begin{array}{l}\text { Cool, fully } \\
\text { humid } \\
\text { winters } \\
\text { with } \\
\text { warm } \\
\text { summer }\end{array}$} & -6.72 & -13.54 & 6.82 \\
\hline Brest, Belarus (4) & $294 \mathrm{~km} \mathrm{E}$ & $52^{\circ} 5^{\prime} 40^{\prime \prime} 23^{\circ} 42^{\prime} 21^{\prime \prime}$ & 136 & & -5.38 & -14.78 & 9.4 \\
\hline Berlin, Germany (27) & $257 \mathrm{~km} \mathrm{~W}$ & $52^{\circ} 28^{\prime} 12^{\prime \prime} 13^{\circ} 24^{\prime} 00^{\prime \prime}$ & 50 & & -6.4 & -9.94 & 3.54 \\
\hline Uhlirska, Czech (4) & $220 \mathrm{~km} \mathrm{SW}$ & $50^{\circ} 49^{\prime} 57^{\prime \prime} 15^{\circ} 8^{\prime} 52^{\prime \prime}$ & 823 & & -5.6 & -12.95 & 7.35 \\
\hline Kopydłowo & $\mathrm{x}$ & $52^{\circ} 45^{\prime} 60^{\prime \prime} 18^{\circ} 19^{\prime} 70^{\prime \prime}$ & 104 & & -6.05 & -12.28 & 6.23 \\
\hline
\end{tabular}

populations had either significantly different diets, or were subject to different environmental conditions. In addition, the TRB group were slightly more widely distributed than the LBK group, suggesting that the later TRB group may have been subject to more varied pastoral practises.

For comparative purposes, 60 compound-specific $\delta^{13} \mathrm{C}_{16: 0}$ and $\delta^{13} \mathrm{C}_{18: 0}$ values of residues identified as animal fats from the LBK and TRB periods were also used (Roffet-Salque and Evershed 2015) (Table 5). For the LBK period, the $\delta^{13} \mathrm{C}_{16: 0}$ range is -29.3 to $-25.3 \%$ whilst the $\delta^{13} \mathrm{C}_{18: 0}$ range is -31.7 to $-27.2 \%$ o. For the TRB period, the $\delta^{13} \mathrm{C}_{16: 0}$ range is -28.9 to $-25.8 \%$ and the $\delta^{13} \mathrm{C}_{18: 0}$ range is -33.3 to $-27.0 \%$. The $\Delta^{13} \mathrm{C}\left(=\delta^{13} \mathrm{C}_{18: 0^{-}} \delta^{13} \mathrm{C}_{16: 0}\right)$ proxy was used in order to identify the fat types by emphasizing the influence of animal metabolism (Copley et al. 2003; Dunne et al. 2012). The ruminant carcass fats most likely originate from cattle; however, at this stage, it is impossible to exclude other ruminants, such as sheep and goats, as sources of carcass fats in the pots because their bulk collagen $\delta^{13} \mathrm{C}$ values have yet to be recorded.
The oxygen isotope raw data for each analysed sample, presented in Table 2, include the maximum, minimum and range in $\delta^{18} \mathrm{O}_{\mathrm{PDB}}$ values for each tooth specimen. The total variation was $6.9 \% \circ(-4.4$ to $-11.3 \%$ o $)$ and the intra-tooth variation ranged from 3.06 to $4.86 \%$. The analytical precision was tested with two standards which showed $0.087 \%$ (FBS) and $0.079 \%$ (LES) variations. In comparison to the variation seen in the archaeological samples, this variation of $<1 \%$ is considered satisfactory in order to proceed with interpretation.

The curves constructed from the $\delta^{18} \mathrm{O}_{\mathrm{PDB}}$ values in the sequential sampling of each tooth specimen are displayed in Fig. 5. The curves in the left column are of second mandibular molars and on the right are the third mandibular molars. The curves in the top row are TRB specimens, the middle row has the TRB/Late Lengyel specimen and the bottom row has the Late Lengyel specimen - the goat second and third mandibular molars. The $\delta^{18} \mathrm{O}_{\mathrm{PDB}}$ curves of the goat (bottom row) and caprines (middle and top row) show maximum and minimum peaks points that can be related to water ingestion that is
Fig. 4 Averaged annual cycle of $\delta^{18} \mathrm{O}_{\text {VSMOW }}$ values in GNIP stations near Kopydłowo (data retrieved 30.04.2015), and modelled annual curve for Kopydłowo derived from Brest and Berlin data

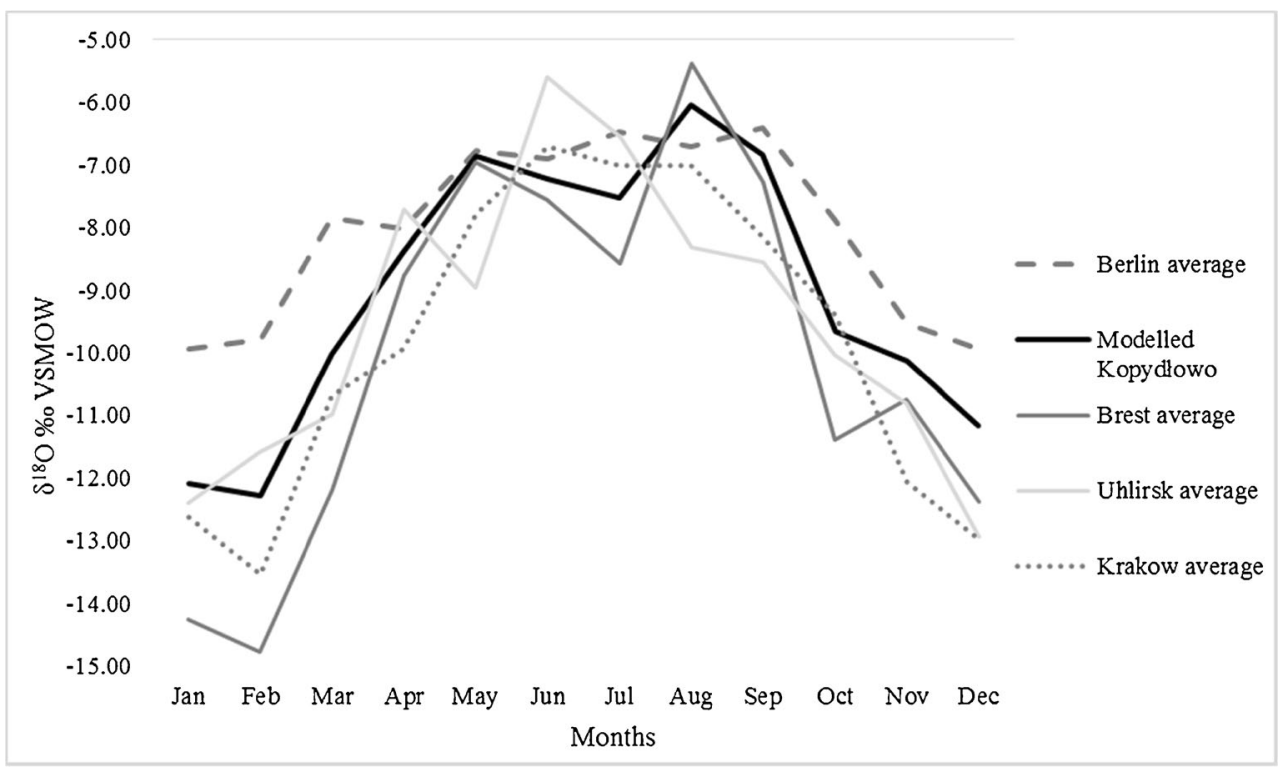


Table 5 Kopydłowo, site 6. List of potsherds sampled for lipids' analysis (after Roffet-Salque, Evershed, 2015)

\begin{tabular}{|c|c|c|c|c|c|}
\hline Sample name & Vessel type & Culture & $\begin{array}{l}\delta^{13} \mathrm{C}_{16: 0} \\
{[\% o]}\end{array}$ & $\begin{array}{l}\delta^{13} \mathrm{C}_{18: 0} \\
{[\% \circ]}\end{array}$ & $\begin{array}{l}\Delta^{13} \mathrm{C} \\
{[\% o]}\end{array}$ \\
\hline KOP2921 & sieve & LBK & -26.0 & -31.7 & -5.7 \\
\hline KOP2922 & kümpfe D & LBK & -25.7 & -27.9 & -2.2 \\
\hline KOP2923 & kümpfe D & LBK & -26.6 & -26.8 & -0.3 \\
\hline KOP2924 & kümpfe D & LBK & nd & nd & nd \\
\hline KOP2925 & kümpfe D & LBK & - & - & - \\
\hline KOP2926 & kümpfe D & LBK & nd & nd & nd \\
\hline KOP2927 & kümpfe D & LBK & -26.8 & -29.6 & -2.9 \\
\hline KOP2928 & sieve & LBK & -26.5 & -31.0 & -4.5 \\
\hline KOP2929 & kümpfe D & LBK & -26.2 & -28.1 & -2.0 \\
\hline KOP2930 & kümpfe D & LBK & - & - & - \\
\hline KOP2931 & kümpfe D & LBK & -29.3 & -30.5 & -1.1 \\
\hline KOP2932 & kümpfe D & LBK & -26.6 & -28.5 & -1.9 \\
\hline KOP2933 & kümpfe D & LBK & -26.2 & -28.1 & -1.9 \\
\hline KOP2934 & kümpfe D & LBK & -25.9 & -27.5 & -1.6 \\
\hline KOP2935 & bowl C & LBK & - & - & - \\
\hline KOP2936 & kümpfe D & LBK & -26.7 & -29.0 & -2.4 \\
\hline KOP2937 & bowl C & LBK & -26.0 & -27.8 & -1.7 \\
\hline KOP2938 & kümpfe D & LBK & -25.7 & -27.9 & -2.2 \\
\hline KOP2939 & sieve & LBK & - & - & - \\
\hline KOP2940 & amphora? & LBK & - & - & - \\
\hline KOP2941 & kümpfe D & LBK & -27.0 & -28.4 & -1.4 \\
\hline KOP2942 & kümpfe D & LBK & -26.8 & -28.7 & -1.9 \\
\hline KOP2943 & kümpfe D & LBK & -26.5 & -28.3 & -1.8 \\
\hline KOP2944 & kümpfe D & LBK & -26.2 & -27.2 & -1.0 \\
\hline KOP2945 & bowl C & LBK & - & - & - \\
\hline KOP2946 & kümpfe D & LBK & -25.3 & -28.0 & -2.6 \\
\hline KOP2947 & kümpfe D & LBK & nd & nd & nd \\
\hline KOP2948 & kümpfe D & LBK & -26.8 & -28.6 & -1.8 \\
\hline KOP2949 & kümpfe $\mathrm{D}$, miniature & LBK & -25.5 & -29.4 & -3.9 \\
\hline KOP2950 & kümpfe D & LBK & -26.5 & -28.9 & -2.4 \\
\hline KOP2951 & beaker & TRB & -26.4 & -32.4 & -6.0 \\
\hline KOP2952 & beaker & TRB & -26.7 & -32.4 & -5.7 \\
\hline KOP2953 & beaker & TRB & -26.7 & -30.9 & -4.3 \\
\hline KOP2954 & bowl & TRB & -26.8 & -32.2 & -5.4 \\
\hline KOP2955 & beaker & TRB & - & - & - \\
\hline KOP2956 & beaker & TRB & -26.7 & -32.6 & -5.9 \\
\hline KOP2957 & $?$ & TRB & - & - & - \\
\hline KOP2958 & beaker & TRB & - & - & - \\
\hline KOP2959 & beaker & TRB & -26.8 & -29.6 & -2.7 \\
\hline KOP2960 & beaker? & TRB & -28.9 & -33.3 & -4.4 \\
\hline KOP2961 & amphora & TRB & - & - & - \\
\hline KOP2962 & beaker & TRB & -27.6 & -33.1 & -5.4 \\
\hline KOP2963 & beaker & TRB & -27.5 & -32.8 & -5.3 \\
\hline KOP2964 & beaker & TRB & -26.8 & -31.4 & -4.6 \\
\hline KOP2965 & casserole & TRB & -27.7 & -29.3 & -1.7 \\
\hline KOP2966 & pot & TRB & - & - & - \\
\hline KOP2967 & pot & TRB & -27.0 & -29.7 & -2.7 \\
\hline KOP2968 & beaker & TRB & -28.3 & -33.0 & -4.8 \\
\hline
\end{tabular}


Table 5 (continued)

\begin{tabular}{lllll}
\hline Sample name & Vessel type & Culture & $\delta^{13} \mathrm{C}_{16: 0}$ & $\begin{array}{c}\delta^{13} \mathrm{C}_{18: 0} \\
{[\%]}\end{array}$ \\
\hline KOP2969 & bowl without base & TRB & $\begin{array}{c}\Delta^{13} \mathrm{C} \\
{[\% \text { o }]}\end{array}$ \\
KOP2970 & bowl? & TRB & - & - \\
KOP2971 & collared flask & TRB & -25.8 & -27.0 \\
KOP2972 & ? & TRB & - & - \\
KOP2973 & collared flask & TRB & - & - \\
KOP2974 & beaker & TRB & - & - \\
KOP2975 & amphora & TRB & -27.0 & -31.2 \\
KOP2976 & ? & TRB & -26.4 & -27.9 \\
KOP2977 & beaker & TRB & -26.6 & -28.9 \\
KOP2978 & beaker & TRB & -28.1 & -32.8 \\
KOP2979 & beaker & TRB & -27.2 & -1.6 \\
KOP2980* & conical pot & TRB & -27.4 & -32.2 \\
\hline
\end{tabular}

Footnote:

* - Ruminant adipose fat

enriched in summer and depleted in winter. The $\delta^{18} \mathrm{O}_{\mathrm{PDB}}$ curve for the sheep (top row) neither tops nor bottoms out clearly; nevertheless, this truncated range is the highest at $4.86 \%$. All these curves allow discussion of variations in seasonal water uptake over nearly an annual cycle.

Considering the $\delta^{18} \mathrm{O}_{\mathrm{PDB}}$ curves generated from sequential sampling of both goat teeth (Sp. 7 and 1), the continuation of the curve from one to the other with only a slight overlap is consistent with the timing of second and third mandibular molar tooth development. This extends the period of analysis, incorporating three consecutive summers and two winters, and allows inter-annual variability in water intake and potentially in precipitation to be discussed. The sequence in these two teeth also reveals the relationship in curve progression between second and third mandibular molars.

Figure 6 presents the maximum, minimum and range in $\delta^{18} \mathrm{O}_{\mathrm{PDB}}$ values for each tooth specimen. The maximum $\delta^{18} \mathrm{O}_{\mathrm{PDB}}$ values range from $-4.4 \%$ ( $\mathrm{Sp.}$ 2) down to $>-6.42 \%$ (Sp. 5). The minimum $\delta^{18} \mathrm{O}_{\mathrm{PDB}}$ values range from -7.9 (Sp. 1) down to <-11.3 (Sp. 5). The ranges extend from $3.06 \%$ (Sp. 1) to $4.74 \%$ o (Sp.7).

The data from the enamel shows a range of $\mathrm{Sr}$ isotope between 0.7117 and 0.7130 (Table 3). Such values would be typical of Palaeozoic rock substrate in the UK (Evans et al. 2010). The Sr concentrations show a moderately wide range of results between 90 and $184 \mathrm{ppm}$. The data from the bone samples has significantly higher $\mathrm{Sr} \mathrm{ppm}$, reflecting reequilibration with the burial environment. The $\mathrm{Sr}$ isotope values from the bone provide an estimate for the local burial environment.

\section{Animal husbandry practises in the lowland LBK and the TRB communities from the stable isotope perspective}

Stable isotopes make it possible to address the unexplored dimensions of prehistoric animal husbandry practises going far beyond the heuristic potential of zooarchaeological studies. A number of intertwined aspects of cattle and caprine husbandry of the LBK and TRB communities from Kopydłowo have been scrutinised, including birthing location and seasonality, diet, pasturing pattern, foddering and herding responses to inferred changes in climate. However, the small sample for $\delta^{13} \mathrm{C}, \delta^{15} \mathrm{~N}$, and $\delta^{18} \mathrm{O}$ analyses from both settlements does not allow to formulate far-reaching conclusions. As the results are showcasing the potential of this approach, it invites large sample size from the region to produce a more complex picture of husbandry practises.

\section{Caprine birthing}

As presented above, the sequential $\delta^{18} \mathrm{O}$ curves taken from the goat second and third molars makes it possible to offer tentative speculations on their birth seasonality (Fig. 5). Both the goat and the TRB/Late Lengyel caprine have similar curve progressions, suggesting that the seasonality of enamel formation, and therefore the birth of both animals, was the same (Balasse et al. 2003; Blaise and Balasse 2011). The curve of $\delta^{18} \mathrm{O}$ values in the TRB sheep M2 ends only slightly earlier in the annual cycle, suggesting it was born slightly later in the same season. Whereas the curve of $\delta^{18} \mathrm{O}$ values in the TRB 


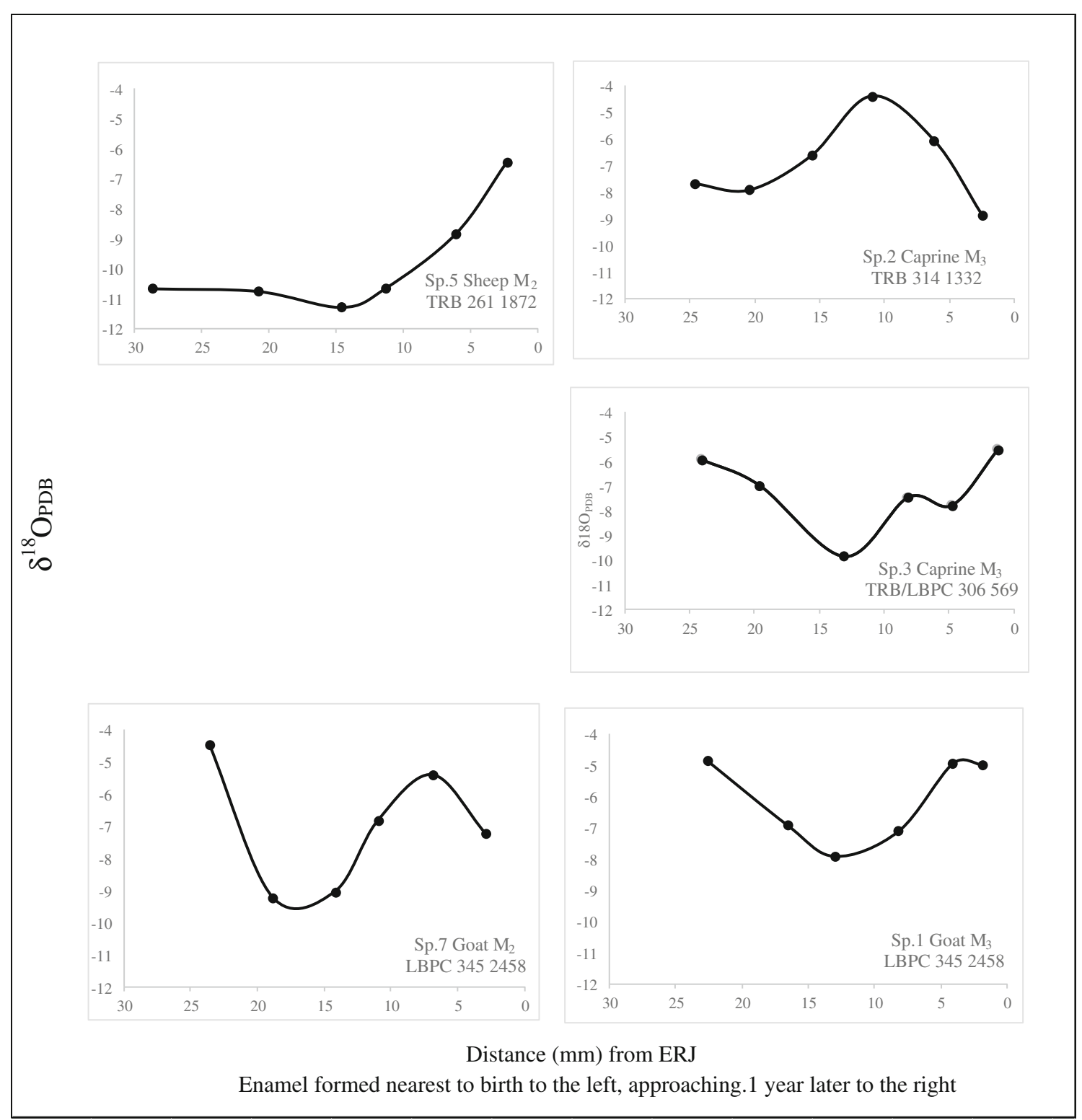

Fig. 5 Kopydłowo, site 6. Charts of $\delta^{18} \mathrm{O}_{\mathrm{PDB}}$ values in sequential samples taken from five tooth specimens

caprine ends at the opposite point of the annual cycle, consistent with a 6-month difference in the timing of enamel precipitation due to it having been born in a different season 6 months apart. This interpretation should be taken cautiously due to low sample resolution and non-normalised tooth length; nevertheless, both caprine ethology and early husbandry practises offer some support to seasonal variation on birthing season. In temperate climates, sheep and goat births are largely confined to spring, although autumn births rarely occur. The TRB caprine might have been born in a different season as a result of poor mating management or conversely, with intensive control of the breeding condition of both ewe and ram by controlling the dietary nutritional plane (Dahl and Hjort 1976), might possibly be the result of managed birth season manipulation.

\section{Cattle and caprine diet}

Carbon isotopes of cattle, sheep, goats and sheep/goats from both LBK and TRB settlements range from -22.7 to $-19.8 \%$ o and show a $\mathrm{C}_{3}$ plant-based terrestrial diet (Fig. 7). The carbon isotope value cut-off for pure $\mathrm{C}_{3}$ plant consumption according to O'Leary (1988) (based on global averages of plants) should be $-22 \%$, with most researchers using $>-19 \%$ (see Fuller et al. 2012 for discussion). Individuals with higher carbon isotope values would suggest the input of some $\mathrm{C}_{4}$ plants in their diet. Using the local LBK Vaihingen mean plant carbon isotope value of $-24 \%$ (Table 6), no animals at Kopydłowo, site 6 , are implicated as having consumed $\mathrm{C}_{4}$ plants since the highest carbon isotope value is $-19.8 \%$ (applying the $5 \%$ o enrichment factor between plant and consumer). A number 


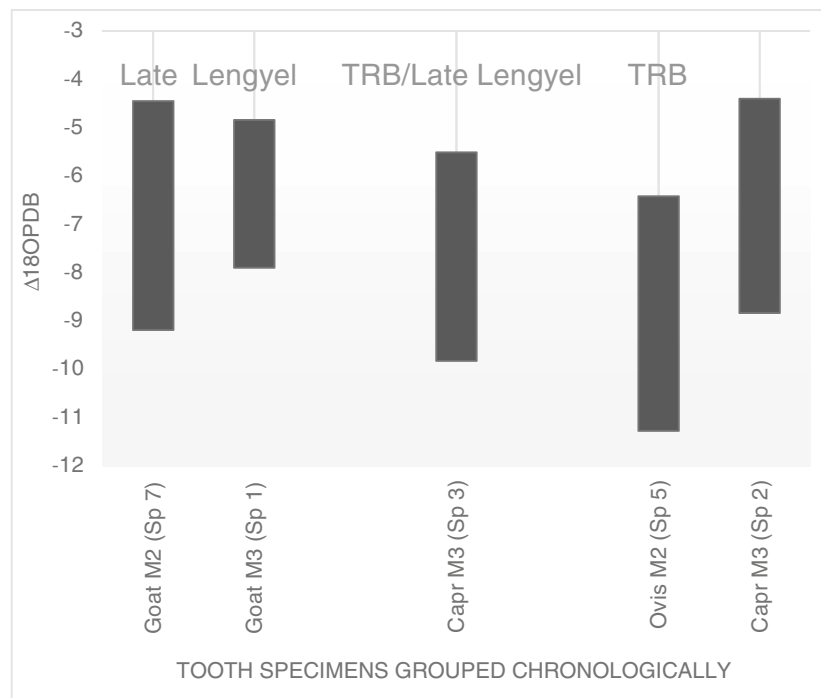

Fig. 6 Kopydłowo, site 6. Chart displaying maximum (top of columns), minimum (bottom of columns) and range (length of columns) in $\delta^{18} \mathrm{O}_{\mathrm{PDB}}$ values for each tooth specimen

of individuals have carbon isotope values as low as -21 and $-22 \%$, many of which are cattle. Without the range for $\mathrm{C}_{3}$ and $\mathrm{C}_{4}$ plants in the area, it is difficult to interpret these data as evidence of environment in which they were herded.

It is notable that the $\delta^{13} \mathrm{C}$ values of lipids $\left(\delta^{13} \mathrm{C}_{16: 0}\right)$ preserved in LBK and TRB potsherds $(-26.4$ and $-27.1 \%$, respectively) are ca. $6 \%$ more depleted than bulk $\delta^{13} \mathrm{C}$ values of collagen from cattle bones (see Roffet-Salque and Evershed 2015). This difference can be explained in the light of feeding experiments showing that $\delta^{13} \mathrm{C}$ values of lipids are ca. $6 \%$ more depleted than bulk $\delta^{13} \mathrm{C}$ values of collagen (Howland et al. 2003). Hence, the mean $\delta^{13} \mathrm{C}$ values of bulk collagen from bones are in an agreement with the ruminant carcass fats preserved in pots. Both lines of evidence show that domestic animals at both settlements in Kopydłowo had a $\mathrm{C}_{3}$ plantbased terrestrial diet.

The nitrogen isotope values are ranging from 5.7 to $8.7 \%$ and are similar to Vaihingen an der Enz (Fraser et al. 2013a, b). The source of this variation is difficult to determine without further work, but at present seems to be largely related to chronological period, with the earlier LBK phase exhibiting values lower than in the later TRB phase, making it very similar to the distribution of carbon isotope values from both settlements.

\section{Cattle pasturing}

Carbon and nitrogen isotope values on bone collagen have also been used for identifying type of environment in which the cattle were herded, both in the LBK and TRB periods. Lighter carbon isotope values can be indicative of a more wooded environment (e.g. van der Merwe and Medina 1989; Drucker et al. 2008), although other explanations cannot be ruled out. A significant difference in both carbon $(p=0.003)$ and nitrogen $(p=<0.001)$ values in cattle from both settlements seems to imply that the cattle populations were subject to different environmental conditions or alternatively they had significantly different diets (Fig. 7). Moreover, the TRB group was slightly more widely distributed than the LBK group, suggesting that it may have been subject to more varied pastoral practises.

The Kopydłowo settlements were located next to a lake (Marciniak et al. 2015b), and one could have expected that animals could have consumed a diet richer in aquatic plants in

Fig. 7 Kopydłowo, site 6. $C$ and $N$ values for animal bones $(n=30)$. Filled symbols represent the LBK phase, whilst empty symbols represent the TRB phase

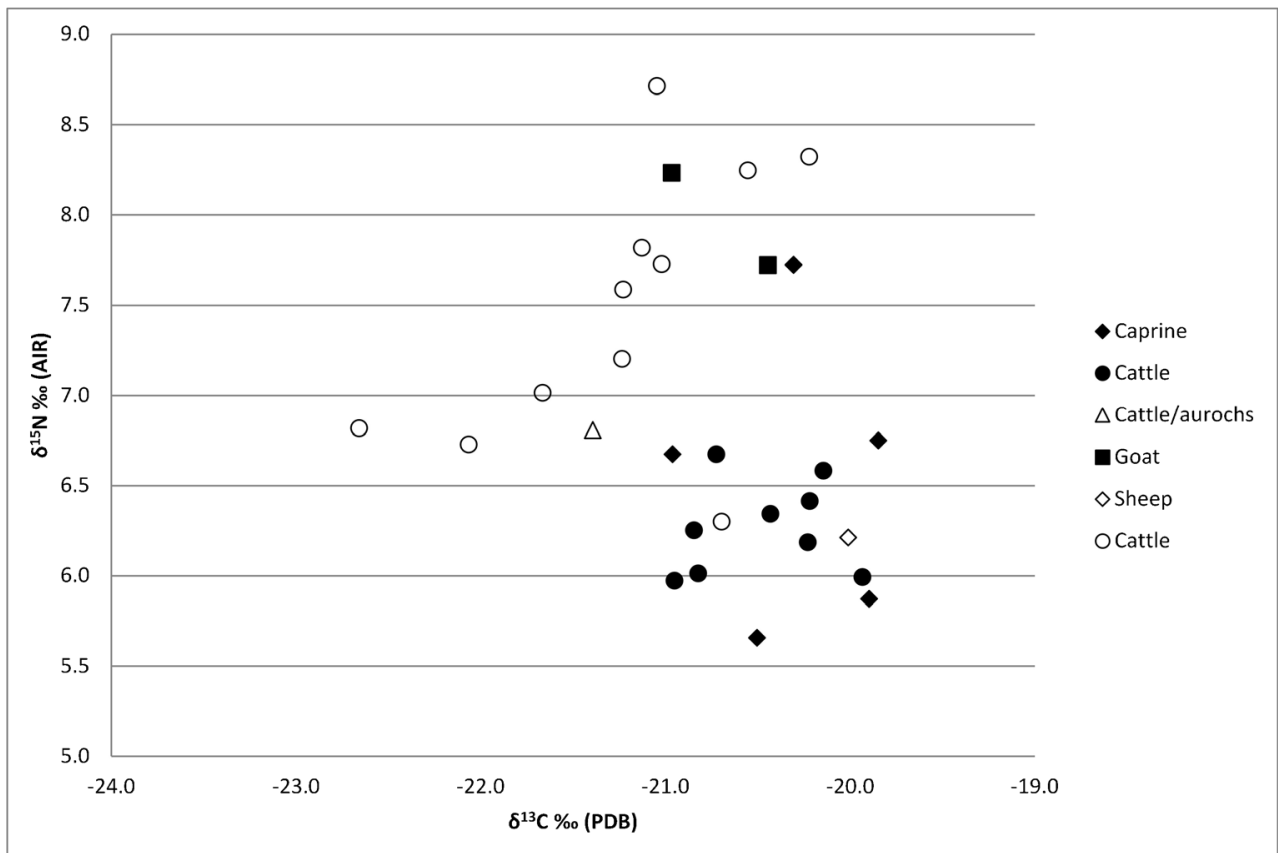


Table 6 Plant stable isotope data from Vaihingen an der Enz (after Fraser et al. 2013a, b)

\begin{tabular}{lll}
\hline Taxon/takson & Number & $\delta^{13} \mathrm{C} \%$ (PDB) \\
\hline Einkorn (1-seeded) & 25 & -24.8 \\
Einkorn (1-seeded) & 25 & -24.2 \\
Einkorn (1-seeded) & 25 & -24.3 \\
Einkorn (1-seeded) & 25 & -24.2 \\
Einkorn (1-seeded) & 15 & -23.6 \\
Einkorn (1-seeded) & 25 & -23.8 \\
Einkorn (2-seeded) & 15 & -23.6 \\
Einkorn (2-seeded) & 25 & -24.5 \\
Glume wheat (new type) & 25 & -24.7 \\
Emmer & 25 & -24.6 \\
Emmer & 25 & -23.9 \\
Emmer & 25 & -23.5 \\
Emmer & 25 & -23.4 \\
Lentil & 25 & -23.1 \\
Pea & 25 & -24.0 \\
Pea & 25 & -23.7 \\
Average & & -24.0 \\
Standard deviation & & 0.5 \\
\hline
\end{tabular}

both periods. As pointed out by Mukherjee et al. (2005), the main source of variation in $\delta^{13} \mathrm{C}$ values of ruminant carcass fats can relate to contribution of $\mathrm{C}_{3}, \mathrm{C}_{4}$ and aquatic resources to the diet of animals; however, the 'canopy' effect cannot be ruled out here. However, this has been contradicted by mean $\delta^{13} \mathrm{C}_{16: 0}$ values of animal fats identified as ruminant carcass as well as isotope values from bone collagen. As mentioned above, the mean $\delta^{13} \mathrm{C}_{16: 0}$ values of animal fats identified as ruminant carcass fats extracted from LBK, Late Lengyel and TRB sherds are $-26.5,-27.2$ and $-26.8 \%$, respectively. The $\delta^{13} \mathrm{C}_{16: 0}$ values are significantly ca. $0.7 \%$ o depleted in Late Lengyel sherds compared to LBK sherds (Kruskal-Wallis test, $p=0.002$ ), and ca. $0.3 \%$ depleted in TRB sherds as compared with LBK sherds (Kruskal-Wallis, $p=0.215$ ) (see RoffetSalque and Evershed 2015).

A slight depletion in $\delta^{13} \mathrm{C}$ values of carcass fats from the TRB period in comparison to LBK may have also been caused by the practice of herding ruminant animals in more forested environments (Drucker et al. 2008). However, foddering with twigs and tree leaves would have affected their $\delta^{13} \mathrm{C}$ values in a similar way. This seems to be corroborated by a detailed multiproxy study of the palaeoenvironment carried out at Osłonki, a region situated around $50 \mathrm{~km}$ to the NW of Kopydłowo (Bogucki et al. 2012), where settlements from the LBK and Late Lengyel periods (5500 and $4000 \mathrm{BC}$ ) were excavated (Grygiel 2004, 2008). Pollen diagrams imply the Late Lengyel groups utilised the surrounding forests for grazing and gathering more than during the preceding LBK period (Bogucki et al.
2012). Given this observation, it seems that the more likely explanation for the changes in carbon isotopic composition from the LBK to the Late Lengyel and then TRB is the increased role played by the forests in animal's diet in the latter Kopydłowo settlement.

A different dimension of pasturing practises was revealed by the $\mathrm{Sr}$ isotope analysis. The samples from the tooth enamel of TRB animals have higher ${ }^{87} \mathrm{Sr} /{ }^{86} \mathrm{Sr}$ values than those from the LBK animals (Table 3; Fig. 8), which suggests the inhabitants of two Kopydłowo settlements exploited different aspects of the environment. The TRB enamel samples are similar in isotope composition to the control bone samples, the values from which reflect the local burial environment. The LBK animals are lower than the estimate for the local environment, suggesting that they may have been raised on terrain that is different. What cannot be determined, due to lack of reference data, is whether the difference in values from the two groups reflects relatively local variation or necessitates the LBK coming from significantly further away. It is worth reiterating that as the sample sizes are small, further work with larger sample sizes is needed to explore this further.

\section{Caprine pasturing and foddering}

The distribution of oxygen isotope values on TRB caprine tooth has been used for the recognition of herding seasonality (Fig. 5). The $\delta^{18} \mathrm{O}$ values form the sinusoidal curve imply most that are consistent with ingested water derived from seasonal Northern Temperate rain, as modelled by modern isotopes in precipitation data in Fig. 4. Caprines receive almost all their water intake from plant tissue, and it is likely that the TRB caprine ate plants which were rain-fed and not irrigated from wells or springs. Irregularities in the sinusoidal curve are indicative of loss of seasonality that might be due to winter fodder. Summer-grown plants added enriched $\delta^{18} \mathrm{O}$ values to the expected winter signature. Conversely, loss of seasonality might be due to summer relocation to cooler wetter pastures with depleted $\delta^{18} \mathrm{O}$ values contributing to the expected summer signature (Henton 2015).

The smooth sinusoidal curves for the caprines and the goat from the TRB settlement at Kopydłowo (Fig. 5) are indicative of both animals remaining in the same place all year round feeding on plants watered throughout the cycle of that location's seasons. There is no suggestion of uphill movement as the summer peak is not flattened due to the more depleted isotopic values associated with cooler, damper uphill summers (Henton 2012; Poage and Chamberlain 2001). However, it cannot be dismissed that foddering accounts for the $\delta^{18} \mathrm{O}$ differences in inter-annual minima between the 2 years of the goat second and third molar formation, but only during its second winter (Henton 2015).

The $\delta^{18} \mathrm{O}$ curve from the Late Lengyel/TRB caprine and the TRB sheep clearly deviate from the sinusoidal but their 
Fig. 8 Kopydłowo, site 6. The $\mathrm{Sr}$ isotope ratios from the enamel and bone plotted against the $\mathrm{Sr}$ concentrations. Filled rombs represent cattle enamel, filled squares represent pig enamel, whilst filled triangles represent bone

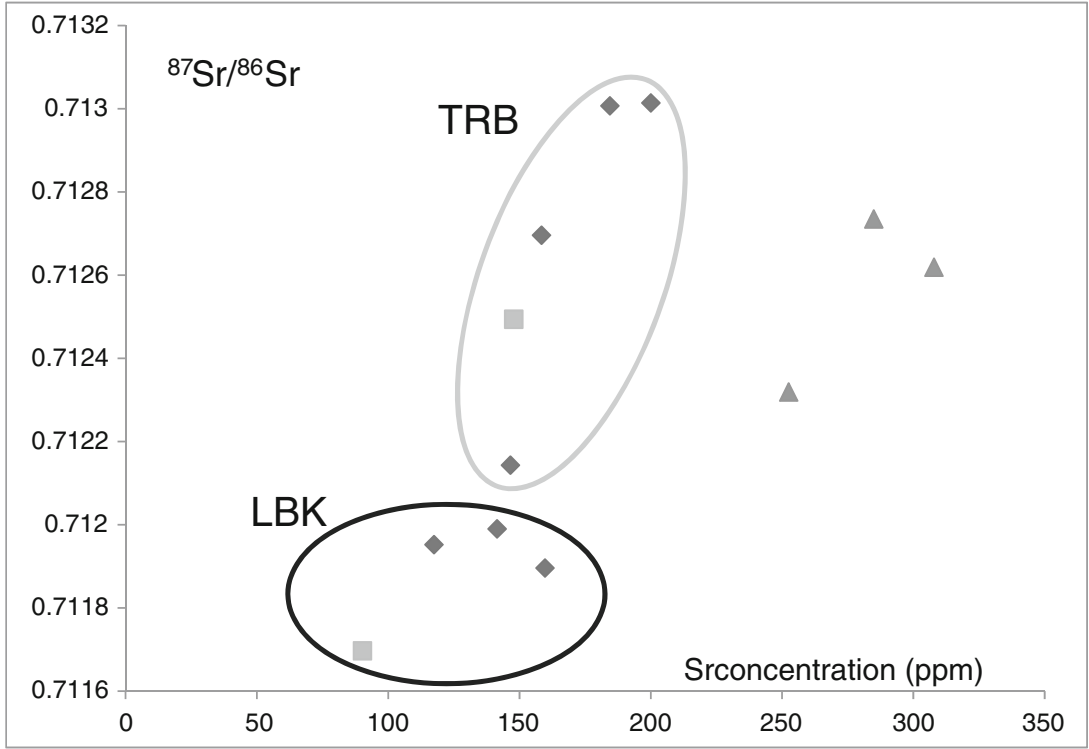

interpretation is far from straightforward. The caprine curve deviates in early summer, which is the time in which pastures are at their most productive and temperatures are rising, making foddering or herd movement to warmer locations unlikely strategies. The $\delta^{18} \mathrm{O}$ curve for the sheep has the long depleted section in autumn but it is unlikely it was moved uphill in the period of the year when temperatures would be falling, nor that it was foddered during a dew-led autumn flush of grass (Henton 2015).

\section{Climatic conditions of caprines herding}

Climate volatility (Gronenborn 2009) rather than foddering appears to be the more likely explanation for the Late Lengyel/TRB caprine curve deviating in early summer. It may have been caused by an unseasonably hot spell in early summer that year. Lower than expected maximum and minimum $\delta^{18} \mathrm{O}$ values for the sheep (Fig. 6) may be the result of the animal experienced a particularly cool summer and winter

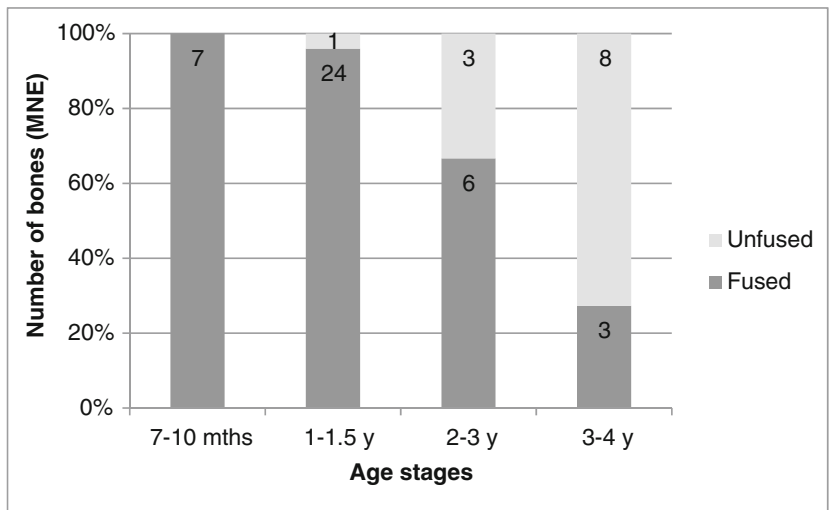

Fig. 9 Kopydłowo, site 6. TRB cattle age-at-death stages based on epiphysial fusion of postcranial skeleton with a hard autumn that year. Rather than the introduction of fodder in the second year for the TRB goat, climate volatility may well be responsible for the detected difference in the two annual minima (Henton 2015).

\section{Husbandry practises in the Early and Middle Neolithic in the Polish lowlands. An integrated perspective}

Whilst studies of carbon and nitrogen isotopes to address animal husbandry strategies in the European Neolithic are relatively common (see, e.g. Le Bras-Goude et al. 2010; Oelze et al. 2011; Robson et al. 2015), an integrated analysis of four major stable isotopes: carbon, nitrogen, oxygen and strontium from a single site marks the new development in these studies. It made it possible to address a number of hitherto unrecognised dimensions of animal husbandry practices such as birthing, seasonality of food provision, animal diet or herd movements, significantly expanding a heuristic potential of faunal studies. It also revealed significant differences in subsequent aspects of husbandry practises performed by the LBK and TRB farming communities from Kopydłowo. Moreover, by combining with faunal, molecular and archaeological strands of evidence, one can set up an integrated and multiproxy research model of animal husbandry studies. Its results can further contribute to addressing a wide range of broader issues, such as resource sharing, landscape exploitation or humans' responses to changes in climate.

Cattle, sheep, goats and sheep/goats from LBK and TRB settlements at Kopydłowo seemed to have terrestrial $C_{3}$ plantbased diet of temperate climate, as indicated by carbon isotope values (Oelze et al. 2011:273; see also Dürrwächter et al. 2006). Both groups, however, may have implemented different strategies of livestock management, in particular in terms of herding and feeding practises, as indicated by a significant 
difference in carbon and nitrogen isotope values of cattle, with earlier LBK settlement exhibiting values lower than in later TRB settlement (see Oezle et al. 2011:277). This variation might be introduced by browsing or grazing in different habitats with distinct isotopic baselines. However, use of different foddering cannot be ruled out. TRB cattle most likely exploited increasingly diverse ecological zones and may have been subject to more varied pastoral practises, as compared with its LBK counterparts, considering their carbon and nitrogen isotopic data was more widely distributed. Expansion of grazing territory for TRB cattle is further corroborated by more variable ${ }^{87} \mathrm{Sr} /{ }^{86} \mathrm{Sr}$ values. Changes in these values between these two periods imply that some of the cattle were not all local to the Kopydłowo settlements, which may have been linked with the increase in grazing lands over larger geographic ranges (Giblin 2009:496). LBK cattle and caprine may have been fed on a similar diet and used a similar kind of pasture, most likely semi-open woodlands, as implied by elevated and the narrow range of $\delta^{13} \mathrm{C}$ values, similar to that reported for wild herbivores from the German LBK sites (Oelze et al. 2011: 274). They were neither grazed in dense deciduous or boreal forests or open landscape. However, this interpretation has to be treated with caution as a wide range of environmental factors could be affecting the values observed (such as water/rainfall, etc.).

One cannot rule out that grazing of the cattle in the forest may have been supplemented by the feed with tree leaves and/ or twigs, which appears to have been more frequently practised. The development of a proxy for the determination of the input of lignin-rich foodstuffs (tree leaves and twigs) in the animal's diet using compound-specific amino-acid $\delta^{15} \mathrm{~N}$ analyses of collagen will doubtless reveal more insights into management practises at this site (see Roffet-Salque and Evershed 2015). The slightly enriched $\delta^{15} \mathrm{~N}$ values in some of TRB cattle (see Fig. 7) can be the effect of nitrogen enrichment in the fodder plants, which happens when they were intensively cultivated and fertilised with animal manure (e.g. Bogaard et al. 2007, 2013). A similar isotopic 'manuring-effect' is not confirmed for LBK cattle, which stands in contrast with some of the cattle at the LBK settlement in Karsdorf in Saxony-Anhalt in Germany (Oelze et al. 2011:275). Caprines may have been exposed to yearly winter volatility indicated by sequential oxygen isotope values.

A different dimension of husbandry practises was revealed by zooarchaeological studies, ${ }^{1}$ in particular by examining slaughtering profiles of different species (Lisowski 2015). A vast majority of cattle in TRB was slaughtered in the third or fourth year of age with only few surviving this threshold. A mortality among young cattle was clearly insignificant (Fig. 9). This visible lack of post-lactation slaughter and small

\footnotetext{
${ }^{1}$ Due to a dearth of satisfactory number of animal bones from the LBK settlement, no herd reconstruction is possible.
}

number of individuals of the oldest group may represent a more meat-oriented economy. Whilst the absence of the youngest animals, culled after lactation, may be explained by taphonomy (Brain 1983; Munson and Garniewicz 2003), the taphonomic bias against the oldest animals is less likely. It would suggest that the lack of old individuals, which would include old dairy cows, is native to the assemblage. However, it is possible that their remains might have been a subject to different consumption and depositional practises or the assemblage is just statistically too small to include them. The TRB caprine were also slaughtered after reaching their adulthood. In this group, a number of female goats has been recorded. This observed bias towards older caprine and female goats may be connected to a milk-oriented economy. The preference of cattle with possibly little dairying importance over caprine, conceivably kept for their milk, may suggest the inferior role of dairy in the economy in the TRB communities.

It needs to be reiterated, however, that the presented character of animal husbandry in the LBK and TRB settlements in Kopydłowo needs to be treated with caution. It is based on sheep, goats and cattle, and only some of those data point to differing management. The small sample for carbon, nitrogen and oxygen analyses does not allow chronological comparisons to be made for caprine specimens. Whilst interpretations of birth seasonality inferred from oxygen isotopes sample size for each individual might suggest some manipulation of the breeding cycle, a more robust sample size, where tooth column lengths have been normalised would allow an assessment of the distribution of births by season, and more insight into whether these were due to lack of breeding control or to highly skilled management. Larger sample sizes would also provide a better basis for untangling conflicting explanations, especially between climate and herd management causes. In addition, with more robust sampling, a climate-led interpretation might elucidate whether climate volatility was confined to one season, and might provide evidence supporting increasing dryness over time. Oxygen isotope evidence from comparative samples of at least 10 specimens each might elucidate differences indicating separate herding strategies for goat and sheep, particularly considering a dominance of sheep over goats at majority of settlements. Should such inter-species differences emerge, climate-led explanations become weaker, and it would become possible to disentangle birthing strategies and foddering versus herd movement. A more comprehensive understanding of the causes of variation in ${ }^{87} \mathrm{Sr} /{ }^{86} \mathrm{Sr}$ values is also required to more reliably interpret results of strontium isotopes in addition to systematic isotope mapping of the region.

Despite these limitations, the reconstructed character of husbandry practises and a shift in the exploitation of cattle and caprine at LBK and TRB settlements at Kopydłowo is evident and seems to correspond well with the tempo and character of the intensively researched process of multifaceted developments of the lowlands Neolithic communities. The 
LBK farming groups, moving into previously uninhabited areas, most likely with domestic animals, had a form of the collective and communal rather than individual and kin-based social arrangements. Starting in the Late Lengyel period and further developed in TRB in the Middle Neolithic sites increased in number, became significantly differentiated and spread out in the landscape. These developments were initiated by the emergence of the household that triggered major social developments of far-reaching consequences including changes in the organisation of production activities, and contacts with indigenous foragers (see Marciniak 2013b). Local communities started to practice mixed agriculture, cultivated a wide range of cereals and began extensive mode of husbandry of major domestic species. Cattle and caprine were integrated, forming a stable agro-pastoral economy. Their breeding conditions were getting controlled, the animals grazed in a wide range of ecological zones and husbandry practises were becoming increasing heterogeneous. This eventually led to the intensification of animal exploitation for milk, wool and traction. More intense use of different ecological zones, including forests and wooden area, led also to the increased exploitation of wild species (see Marciniak 2013a).

Open Access This article is distributed under the terms of the Creative Commons Attribution 4.0 International License (http:// creativecommons.org/licenses/by/4.0/), which permits unrestricted use, distribution, and reproduction in any medium, provided you give appropriate credit to the original author(s) and the source, provide a link to the Creative Commons license, and indicate if changes were made.

\section{References}

Ambrose SH (1991) Effects of diet, climate and physiology on nitrogen isotope abundances in terrestrial food webs. J Archaeol Sci 18:293317

Ambrose SH (1993) Isotopic analysis of paleodiets: methodological and interpretative considerations. In: Sandford MK (ed) Investigations of ancient human tissue: chemical analyses in anthropology. Gordon and Breach Science Publishers, Pennsylvania, pp 59-130

Ambrose SH (2000) Controlled diet and climate experiments on nitrogen isotope ratios of rats. In: Ambrose SH, Katzenberg MA (eds) Biogeochemical approaches to paleodietary analysis. Advances in archaeological and museum science, Vol. 5. Kluwer Academic/ Plenum Publishers, New York, pp 243-263

Balasse M (2002) Reconstructing dietary and environmental history from enamel isotopic analysis: time resolution of intra-tooth sequential sampling. Int J Osteoarchaeol 12:155-165

Balasse M, Ambrose S, Smith A, Price D (2002) The seasonal mobility model for prehistoric herders in the south-west Cape of South Africa assessed by isotopic analysis of sheep tooth enamel. J Archaeol Sci 29:917-932

Balasse M, Smith A, Ambrose S, Leigh S (2003) Determining sheep birth seasonality by analysis of tooth enamel oxygen isotope ratios: the Late Stone Age site of Kasteelberg (South Africa). J Archaeol Sci 30:205-215

Balasse M, Evin A, Tornero C, Radu V, Fiorillo D, Popovici D, Andreescu R, Dobney K, Cucchi T, Balasescu A (2016) Wild, domestic and feral? Investigating the status of suids in the Romanian Gumelnita (5th mil. cal BC) with biogeochemistry and geometric morphometrics. J Anthropol Archaeol 42:27-36

Barboza PS, Farley SD, Robbins CT (1997) Whole-body urea cycling and protein turnover during hyperphagia and dormancy in growing bears (Ursus americanus and U-arctos). Can J Zool 75:2129-2136

Bickle P, Whittle A (2013) The first farmers of Central Europe: diversity in LBK Lifeways. Oxbow Book, Oxford

Birck JL (1986) Precision K-Rb-Sr isotopic analysis - application to RbSr chronology. Chem Geol 56(1-2):73-83

Blaise E, Balasse M (2011) Seasonality and season of birth of modern and late Neolithic sheep from South-Eastern France using tooth enamel d18O analysis. J Archaeol Sci 38:3085-3093

Bogaard A, Heaton THE, Poulton P, Merbach I (2007) The impact of manuring on nitrogen isotope ratios in cereals: archaeological implications for reconstruction of diet and crop management practices. J Archaeol Sci 34:335-343

Bogaard A, Fraser R, Heaton THE, Wallace M, Vaiglova P, Charles M, Jones G, Evershed RP, Styring AK, Andersen NH, Arbogast R-M, Bartosiewicz L, Gardeisen A, Kanstrup M, Maier U, Marinova E, Ninov L, Schäfer M, Stephan E (2013) Crop manuring and intensive land management by Europe's first farmers. Proc Natl Acad Sci 110: 12589-12594

Bogaard A, Henton E, Evans J, Twiss K, Charles M, Vaiglova P, Russell N (2014) Locating land use at Neolithic Çatalhöyük, Turkey: the implications of ${ }^{87} \mathrm{Sr} /{ }^{86} \mathrm{Sr}$ signatures in plants and sheep tooth sequences. Archaeometry 56:860-877

Bogucki P (1988) Forest farmers and stockherders. Early agriculture and its consequences in noth-central Europe. Cambridge University Press, Cambridge

Bogucki PI, Nalepka D, Grygiel R, Nowaczyk B (2012) Multiproxy environmental archaeology of Neolithic settlments at Osłonki, Poland, 5500-4000 BC. Environ Archaeol 17(1):45-65

Brain CK (1983) The hunters or the hunted? An introduction to African cave taphonomy. The University of Chicago Press, Chicago

Brown TA, Nelson DE, Vogel JS, Sothon JR (1988) Improved collagen extraction by modified Longin method. Radiocarbon 30:171-177

Bryant J, Froelich P (1995) A model of oxygen isotope fractionation in body water of large mammals. Geochim Cosmochim Acta 59:45234537

Copley MS, Berstan R, Dudd SN, Docherty G, Mukherjee AJ, Straker V, Payne S, Evershed RP (2003) Direct chemical evidence for widespread dairying in prehistoric Britain. Proc Natl Acad Sci 100(4): $1524-1529$

Cormie AB, Schwarcz HP (1994) Stable isotopes of nitrogen and carbon of North American white-tailed deer and implications for paleodietary and other food web studies. Palaeogeogr Palaeoclimatol Palaeoecol 107:227-241

Cormie AB, Schwarcz HP (1996) Effects of climate on deer bone $\delta^{15} \mathrm{~N}$ and $\delta^{13} \mathrm{C}$ : lack of precipitation effects of $\delta^{15} \mathrm{~N}$ for animals consuming low amounts of $\mathrm{C}_{4}$ plants. Geochim Cosmochim Acta 60:41614166

Cucchi T, Dai L, Balasse M, Zhao C, Gao J, Hu Y, Yuan J, Vigne J-D (2016) Social complexification and pig (Sus scrofa) husbandry in ancient China: a combined geometric morphometric and isotopic approach. PLoS One. doi:10.1371/journal.pone.0158523

Czerniak L (1998) The first farmers. In: Chłodnicki M, Krzyżaniak L. (eds) Pipeline of Archaeological Treasures. Poznańskie Towarzystwo Prehistoryczne, Poznań, p 23-36

Dahl G, Hjort A (1976) Having herds: pastoral herd growth and household economy. Stockholm Studies in Social Anthropology, Stockholm

Dansgaard W (1964) Stable isotopes in precipitation. Tellus 16:436-468

Darling W (2004) Hydrological factors in the interpretation of stable isotope proxy data present and past: a European perspective. Quat Sci Rev 23:743-770 
DeNiro MJ (1985) Post-mortem preservation and alteration of in-vivo bone collagen isotope ratios in relation to paleodietary reconstruction. Nature 317:806-809

DeNiro MJ, Epstein S (1978) Influence of diet on the distribution of carbon isotopes in animals. Geochim Cosmochim Acta 42:495-506

Drucker DG, Bridault A, Hobson A, Szuma E, Bochrens H (2008) Can carbon-13 in large herbivores refect the canopy effect in temperate and boreal ecosystems? Evidence from modern and encient ungulates. Paleogeography, Paleoclimatology, Paleoecology 266:69-82

Dunne J, Evershed RP, Salque M, Cramp LJE, Bruni S, Ryan K, Biagetti S, di Lernia S (2012) First dairying in green Saharan Africa in the fifth millennium BC. Nature 486:390-394

Dürrwächter C, Craig OE, Collins MJ, Burger J, Alt KW (2006) Beyond the grave: variability in Neolithic diets in Southern Germany? J Archaeol Sci 33:39-48

Evans JA, Montgomery J, Wildman G, Boulton N (2010) Spatial variations in biosphere Sr-87/Sr-86 in Britain. J Geol Soc 167(1):1-4

Evershed RP, Payne S, Sherratt AG, Copley MS, Coolidge J, Urem-Kotsu D, Kotsakis K, Özdoğan M, Özdoğan A, Nieuwenhuyse O, Akermans PMMG, Bailey DK, Andeescu R-R, Campbell S, Farid S, Hodder I, Yalman N, Özbașaran M, Biçakçi E, Garfinkel Y, Levy T, Burton MM (2008) Earliest date for milk use in the Near East and southeastern Europe linked to cattle herding. Nature 455:528-531

Faber P, Johnstone AM, Gibnet ER, Elia M, Stubbs RJ, Roger PL, Milne E, Buchan W, Lobley GE (2003) The effect of rate and extent of weight loss on urea salvaging in obese male subjects. Br J Nutr 90: 221-231

Fraser R, Bogaard A, Shäfer M, Arbogast R, Heaton THE (2013a) Integrating botanical, faunal and human stable carbon and nitrogen isotope values to reconstruct land use and palaeodiets at LBK Vaihingen an der Enz, Baden-Württemberg. World Archaeol 45: 492-517

Fraser R, Bogaard A, Shäfer M, Arbogast R, Heaton THE (2013b) Integrating botanical, faunal and human stable carbon and nitrogen isotope values to reconstruct land use and palaeodiets at LBK Vaihingen an der Enz, Baden-Württemberg. World Archaeol 45: 492-517

Fricke H, O'Neil J (1996) Inter- and intra- tooth variations in the oxygen isotope composition of mammalian tooth enamel phosphate: implications for palaeoclimatological and palaeobiological research. Palaeogeogr Palaeoclimatol Palaeoecol 126:91-99

Fuller BT, Fuller JL, Sage NE, Harris DA, O'Connell TC, Hedges REM (2005) Nitrogen balance and d15N: why you're not what you eat during nutritional stress. Rapid Commun Mass Spectrosc 19:2497_ 2506

Fuller BT, De Cupere B, Marinova E, Van Neer W, Waelkens M, Richards MP (2012) Isotopic reconstruction of human diet and animal husbandry practices during the classical-Hellenistic, Imperial, and Byzantine Periods at Sagalassos, Turkey. Am J Phys Anthropol 149:157-171

Giblin JI (2009) Strontium isotope analysis of Neolithic and copper Agepopulations on the Great Hungarian Plain. J Archaeol Sci 36: 491-497

Glagoleva TA, Chulanovskaya MV (1992) Photosynthetic metabolism in plants of the family Chenopodiaceae from arid saline regions. Russ J Plant Physiol 39:431-437

Grant A (1982) The use of tooth wear as a guide to the age of domestic ungulates. In: Wilson B, Grigson C, Payne S (eds) Ageing and sexing animal bones from archaeological sites (British Archaeological Reports British series 109). Archaeopress, Oxford, pp 91-108

Grigson C (1982) Sex and age determination of some bones and teeth of domestic cattle: a review of the literature. In: Wilson B, Grigson C, Payne $\mathrm{S}$ (eds) Ageing and sexing animal bones from archaeological sites (British Archaeological Reports British series 109). Archaeopress, Oxford, pp 7-23
Gröcke DR, Bocherens H, Mariotti A (1997) Annual rainfall and nitrogen-isotope correlation in macropod collagen: application as a palaeoprecipitation indicator. Earth Planet Sci Lett 153:279-285

Gronenborn D (2009) Climate fluctuations and trajectories to complexity in the Neolithic: towards a theory. Documenta Praehistorica 36:97110

Grygiel R (ed) (2004) Neolit i początki epoki brązu w rejonie Brześcia Kujawskiego i Osłonek. Tom I. Wczesny neolit. Kultura ceramiki wstegowej rytej. Fundacja Badań Archeologicznych im. Profesora Konrada Jażdżewskiego and Muzeum Archeologiczne i Etnograficzne w Łodzi, Łódź

Grygiel R (ed) (2008) Neolit i początki epoki brązu w rejonie Brześcia Kujawskiego i Osłonek. Tom I. Część I-III. Srodkowy neolit. Grupa brzesko-kujawska kultury lendzielskiej. Fundacja Badań Archeologicznych im. Profesora Konrada Jażdżewskiego and Muzeum Archeologiczne i Etnograficzne w Łodzi, Łódź

Grygiel R, Bogucki P (1997) Early farmers in north-central Europe: 1989-1994 excavations at Osłonki, Poland. J Field Archaeol 24: $161-178$

Halstead P (2011) The faunal remains. In: Pullen DJ (ed) Namea Valley Archaeological Project. Volume 1. The Early Bronze Age Village on Tsoungiza Hill. American School of Classical Studies at Athens, Princeton, pp 741-804

Heaton THE (1987) The ${ }^{15} \mathrm{~N} /{ }^{14} \mathrm{~N}$ ratios of plants in South Africa and Namibia: relationship to climate and coastal/saline environments. Oecologia 74:236-246

Heaton THE (1999) Spatial, species, and temporal variations in the ${ }^{13} \mathrm{C} /{ }^{12} \mathrm{C}$ ratios of $\mathrm{C}_{3}$ plants: implications for palaeodiet studies. $\mathrm{J}$ Archaeol Sci 26:637-649

Heckathorn SA, McNaughton SJ, Coleman JS (1999) $\mathrm{C}_{4}$ plants and Herbivory. In: Sage RF, Monson RK (eds) $\mathrm{C}_{4}$ plant biology. Academic Press, New York, pp 285-312

Hedges REM, Reynard LM (2007) Nitrogen isotopes and trophic level of humans in archaeology. J Archaeol Sci 34:1240-1251

Henton E (2012) The combined use of oxygen isotopes and microwear in sheep teeth to elucidate seasonal management of domestic herds: the case study of Çatalhöyük, central Anatolia. J Archaeol Sci 30:32643276

Henton E (2015) A glimpse into the seasonality of Kopydłowo 6 herd management. The potential offered by the oxygen isotope analysis of Ovis/Capra tooth enamel. In: Marciniak A, Sobkowiak-Tabaka I, Bartkowiak M, Lisowski M (eds) Kopydłowo, stanowisko 6. Osady neolityczne z pogranicza Kujaw i Wielkopolski. Wydawnictwo Profil-Archeo, Poznań-Pękowice, pp 271-280

Hongo H, Pearson J, Öksüz B, Ilgezdi G (2009) The process of ungulate domestication at Çayönü, Southeastern Turkey: a multidisciplinary approach focussing on Bos sp. and Cervus sp. Anthropozoologica 44:63-78

Howland MR, Corr LT, Young SMM, Jones V, Jim S, Van Der Merwe NJ, Mitchell AD, Evershed RP (2003) Expression of the dietary isotope signal in the compound-specific $\delta^{13} \mathrm{C}$ values of pig bone lipids and amino acids. Int J Osteoarchaeol 13(1-2):54-65

Hunt H, Linden MV, Liu XY, Motuzaite-Matuzeviciute G, Colledge S, Jones MK (2008) Millets across Eurasia: chronology and context of early records of genera Panicum and Setaria from archaeological sites in the Old World. Veg Hist Archaeobotany 17:5-18

IAEA/WMO (2014) Global network of isotopes in precipitation. The GNIP Database. http://www.iaea.org/water. Accessed 30 Apr 2015

Iacumin P, Longinelli A (2002) Relationship between $\delta^{18} \mathrm{O}$ values for skeletal apatite from reindeer and foxes and yearly mean $\delta^{18} \mathrm{O}$ values of environmental water. Earth Planet Sci Lett 201:213-219

Le Bras-Goude G, Binder D, Zemour A, Richards MP (2010) New radiocarbon dates and isotope analysis of Neolithic human and animal bone from the Fontbrégoua Cave (Salernes, Var, France). Journal of Anthropological Sciences 88:167-178 
Lisowski M (2014) Hides and horn sheaths. A case study of processed skulls and horn cores from the Early-Middle Neolithic site of Kopydłowo 6, Poland. Assemblage PZAF 2014:31-41

Lisowski M (2015) Materiały zooarcheologiczne ze stanowiska $6 \mathrm{w}$ Kopydłowie. In: Marciniak A, Sobkowiak-Tabaka I, Bartkowiak M, Lisowski M (eds) Kopydłowo, stanowisko 6. Osady neolityczne z pogranicza Kujaw i Wielkopolski. Wydawnictwo Profil-Archeo, Poznań-Pękowice, pp 209-244

Longin R (1971) New method of collagen extraction for radiocarbon dating. Nature 230:241-242

Macko SA, Estep MLF, Hare PL, Hoering TC (1982) Stable nitrogen and carbon isotopic composition of individual amino acids isolated from cultured microorganisms. Annual report of the director, Geophysical Laboratory, Carnegie Institution, Washington, 1981-1982, pp. 404-410

Marciniak A (2005) Placing animals in the Neolithic. Social zooarchaeology of prehistoric farming communities. UCL Press, London

Marciniak A (2008) Interactions between hunter-gatherers and farmers in the Early and Middle Neolithic in the Polish part of the North European Plain. In: Papagianni D, Layton R (eds) Time and change. Archaeological and nnthropological perspectives on the long-term in hunter-gatherer societies. Oxbow, Oxford, pp 115-133

Marciniak A (2011) The secondary products revolution: empirical evidence and its current zooarchaeological critique. J World Prehist 24(2-3):117-130

Marciniak A (2013a) Origin of stock-keeping and spread of animal exploitation strategies in the early and Middle Neolithic of the North European Plains. In: Colledge S, Conolly J, Dobney K, Manning K, Shennan S (eds) The origin and spread of domestic animals in Southwest Asia and Europe. UCL Press, London, pp 221-237

Marciniak A (2013b) The society in the making. The house and the household in the Danubian Neolithic of the Central European lowlands. In: Kerig T, Zimmermann A (eds) Economic archaeology. From structure to performance in European archaeology. Habelt, Bonn, pp 47-63

Marciniak A (2014) The secondary products revolution, mortality profiles, and practice of zooarchaeology. In: Greenfield H (ed) The secondary products revolution in perspective. Oxbow, Oxford, pp 186-205

Marciniak A, Sobkowiak-Tabaka I, Bartkowiak M, Lisowski M (eds) (2015a) Kopydłowo, stanowisko 6. Osady neolityczne z pogranicza Kujaw i Wielkopolski. Wydawnictwo Profil-Archeo, Poznań-Pękowice

Marciniak A, Sobkowiak-Tabaka I, Bartkowiak M, Lisowski M (2015b) Kontekst osadniczy, charakter i chronologia osadnictwa neolitycznego na stanowisku $6 \mathrm{w}$ Kopydłowie. In: Marciniak A, Sobkowiak-Tabaka I, Bartkowiak M, Lisowski M (eds) Kopydłowo, stanowisko 6. Osady neolityczne z pogranicza Kujaw i Wielkopolski. Wydawnictwo Profil-Archeo, Poznań-Pękowice, pp 15-51

van der Merve NJ, Medina E (1989) Photosynthesis and ${ }^{13} \mathrm{C} /{ }^{12} \mathrm{C}$ ratios in Amazonian rain forests. Geochim Cosmochim Acta 53:1091-1094

Milisauskas S, Kruk J (1989) Neolithic economy in Central Europe. J World Prehist 3/4:403-446

Mukherjee AJ, Copley MS, Berstan R, Clark KA, Evershed RP (2005) Interpretation of $\delta^{13} \mathrm{C}$ values of fatty acids in relation to animal husbandry, food processing and consumption in prehistory. In: Mulville J, Outram AK, The zooarchaeology of fats, oils, milk and dairying $-9^{\text {th }}$ ICAZ Conference. Oxbow Books, Durham, pp. 77-93

Munson PJ, Garniewicz RC (2003) Age-mediated survivorship of ungulate mandibles and teeth in canid-ravaged faunal assemblages. J Archaeol Sci 30:405-416

Neil S, Evans J, Montgomery J, Scarre C (2016) Isotopic evidence for residential mobility of farming communities during the transition to agriculture in Britain. Royal Society Open Science 3(1): 150522

O'Leary MH (1981) Carbon isotope fractionation in plants. Phytochemistry 20:553-567
O’Leary MH (1988) Carbon Isotopes in Photosynthesis. Bioscience 38: 328-336

Oelze VM, Siebert A, Nicklisch, Meller H, Dresely V, Alt KW (2011) Early Neolithic diet and animal husbandry: stable isotope evidence from three Linearbandkeramik (LBK) sites in Central Germany. J Archaeol Sci 38:270-279

Payne S (1973) Kill-off patterns in sheep and goats: the mandibles from Asvan Kale. Anatol Stud 23:281-303

Pearson JA, Buitenhuis H, Hedges REM, Martin L, Russell N, Twiss KC (2007) New light on early caprine herding strategies from isotope analysis: a case study from Neolithic Anatolia. J Archaeol Sci 34: 2170-2179

Pearson J, Bogaard A, Charles M, Hillson S, Larsen C, Russell N, Twiss K (2015) Stable carbon and nitrogen isotope analysis at Neolithic Çatalhöyük: evidence for human and animal diet and their relationship to households. J Archaeol Sci 57:69-79

Poage M, Chamberlain C (2001) Empirical relationships between elevation and the stable isotope composition of precipitation and surface waters: considerations for studies of palaeoelevation change. Am J Sci 301:1-15

Robinson D, Handley LL, Scrimgeour CM, Gordon DC, Forster BP, Ellis RP (2000) Using stable isotope natural abundances $(\delta 15 \mathrm{~N}$ and $\delta$ $13 \mathrm{C}$ ) to integrate the stress responses of wild barley (Hordeum spontaneum C. Koch) genotypes. J Exp Bot 51:41-50

Robson HK, Andersen SH, Clarke L, Craig OE, Gron K, Jones A, Karsten P, Milner N, Price TD, Ritchie K, Zabilska-Kunek M, Heron C (2015) Carbon and nitrogen stable isotope values in freshwater, brackish and marine fish bone collagen from Mesolithic and Neolithic sites in central and northern Europe. Environ Archaeol 20:1-14

Roffet-Salque M, Evershed RP (2015) Shifting pottery use and animal management at Kopydłowo (Poland) traced through lipid residue analyses of pottery vessels. In: Marciniak A, Sobkowiak-Tabaka I, Bartkowiak M, Lisowski M (eds) Kopydłowo, stanowisko 6. Osady neolityczne z pogranicza Kujaw i Wielkopolski. Wydawnictwo Profil-Archeo, Poznań-Pękowice, pp 133-142

Rozanski K, Araguas-Araguas L, Gonfiantini R (1993) Isotopic patterns in modern global precipitation. Climate change in continental isotopic records. American Geophysics Union. Geophysics Monograph 78:1-36

Salque M, Radi G, Fabbri C, Tagliacozzo A, Pino Uria B, Wolfram S, Stäuble H, Hohle I, Whittle A, Hofmann D, Pechtl J, Schade-Lindig S, Eisenhauer U, Evershed RP (2012) New insights into the early Neolithic economy and management of animals in Southern and Central Europe revealed using lipid residue analyses of pottery vessels. Anthropozoologica 47(2):45-61

Schwarcz HP, Dupras TL, Fairgrieve SI (1999) ${ }^{15} \mathrm{~N}$ enrichment in the Sahara: in search of a global relationship. J Archaeol Sci 26:629-636

Sealy J, van der Merwe NJ, Lee-Thorp JA, Lanham JL (1987) Nitrogen isotope ecology in southern Africa: implications for environmental and dietary tracing. Geochim Cosmochim Acta 51:2707-2717

Silver I (1969) The ageing of domestic animals. In: Brothwell D, Higgs E (eds) Science in Archaeology, 2nd ed. Thames and Hudson, London, pp 283-302

Stewart GS, Smith CP (2005) Urea nitrogen salvage mechanisms and their relevance to ruminants, non-ruminants and man. Nutr Res Rev 18:49-62

Suga S (1982) Progressive mineralization pattern in developing enamel during the maturation stage. Journal of Dental Research 61 (special issue) $1532-1542$

Szpak P, Millaire JF, White CD, Longstaffe FJ (2014) Small scale camelid husbandry on the north coast of Peru (Viru Valley): insight from stable isotope analysis. J Anthropol Archaeol 36:110-129

Tieszen LL (1991) Natural variations in the carbon isotope values of plants: implications for archaeology, ecology, and palaeoecology. J Archaeol Sci 18:227-248 
Tieszen LL, Fagre T (1993) Carbon isotopic variability in modern and archaeological maize. J Archaeol Sci 20:25-40

van Groenigen J-W, van Kessel C (2002) Salinity-induced patterns of natural abundance carbon-13 and nitrogen-15 in plant and soil. Soil Sci Soc Am J 66:489-498

Van der Merwe NJ, Medina E (1991) The canopy effect, carbon isotope ratios and foodwebs in Amazonia. J Archaeol Sci 18:249-259

Vigne J-D, Helmer D (2007) Was milk a "secondary product" in the Old World Neolithisation process? Its role in the domestication of cattle, sheep and goats. Anthropozoologica 42(2):9-40
Wattiaux MA, Reed JD (1995) Fractionation of nitrogen isotopes by mixed ruminal bacteria. J Anim Sci 73:257-266

Weinreb M, Sharav Y (1964) Tooth development in sheep. Am J Vet Res 25:891-908

Wilson B, Hamilton J, Brothwell D, Armitage P (1978) The animal bones. In: Parrington, M. (ed) The excavation of an Iron Age settlement, Bronze Age ring ditches, and Roman features at Ashebille trading estate, Abingdon (Oxfordshire), 1974-1976 (Research Report 28). Council for British Archaeology, London, pp 110-139 